School of Finance

University of St.Gallen

The Determinants of EFFICIENCY AND Productivity IN THE SWISS INSURANCE INDUSTRY

CHRISTIAN BIENER

MARTIN ELING

JAN HENDRIK WIRFS

WORKING PAPERS ON FinANCE No. 2015/2

INSTITUTE OF INSURANCE ECONOMICS (I.VW-HSG)

JANUARY 2015 


\title{
The Determinants of Efficiency and Productivity in the Swiss Insurance Industry
}

\author{
Christian Biener, Martin Eling, Jan Hendrik Wirfs*
}

\begin{abstract}
Using state-of-the-art frontier efficiency methodologies, we study the efficiency and productivity of Swiss insurance companies in the life, property/casualty, and reinsurance sectors from 1997-2013. The broad scope of this study provides an opportunity to compare and cross-check the findings from other countries, across different time periods, and across different subsectors. Moreover, we are the first to analyze the internationalization strategies of insurance companies, a topic of high interest in the business and economics literature, but one that has not to date been the focus of efficiency studies in the insurance sector. We find that productivity and efficiency in the Swiss insurance market have improved for the property/casualty and reinsurer sectors, but not in the case of life insurance. The results suggest that the internationalization of the insurance business has a positive impact on insurer efficiency. We also illustrate the importance of analyzing nonlinear and interaction effects in second-stage regressions so as to obtain richer insight into the determinants of efficiency. These tests show that being either a small specialist or a large diversified company is optimal from an efficiency point of view. Our findings are of interest not only for Swiss insurance company managers, regulators, and policymakers, but also for academics in other fields and practitioners in other countries.
\end{abstract}

Keywords: Data envelopment analysis, Two-stage double-bootstrap, Internationalization, OR in insurance

\section{Introduction}

As has happened in many other industrialized countries, the Swiss insurance market has undergone major changes over the last 20 years. Deregulation of financial services in the 1990s led to increased competition and internationalization of the insurance business. Capital market conditions changed substantially in a similar manner. Due to historically low interest rates, previously common strategies of significant "safe" bond holdings with long-term maturity

* Christian Biener (christian.biener@unisg.ch), Martin Eling (martin.eling@unisg.ch), and Jan Hendrik Wirfs (jan.wirfs@unisg.ch) are all with the Institute of Insurance Economics at the University of St. Gallen, Rosenbergstrasse 22, 9000 St. Gallen, Switzerland. Early versions of this paper were presented at the 2014 Annual Conference of the Swiss Society of Financial Market Research, at the 2014 Annual Conference Asia-Pacific Risk and Insurance Association, and at the $41^{\text {st }}$ Annual Seminar of the European Group of Risk and Insurance Economists (EGRIE). We are grateful to the conference participants for many helpful comments. 
and high interest rates were rendered problematic as bonds that came to term had to be replaced by such with much lower interest rates. Moreover, changing supervisory and legal frameworks, such as the Swiss Solvency Test introduced in 2006, resulted in the establishment of integrated risk management systems within the insurance companies.

This paper provides an in-depth analysis of the efficiency and productivity development in Switzerland during this period of major changes. Efficiency measurement is one of the fastest growing areas in the business and economics literature and the insurance sector has seen particularly high growth in the number of studies applying efficiency methods (see Eling and Luhnen, 2010a for a review of 95 studies). The Swiss insurance industry, however, has been the subject of relatively little research in this context; to date, it has been considered only in a cross-country context, yielding ambiguous results. ${ }^{1}$

Our study provides sharper insight into the level and determinants of efficiency in the Swiss insurance industry. But for two reasons the importance and scope of the paper stretches beyond the borders of Switzerland. First, while most efficiency studies are restricted to one sector and a relatively short time period, our dataset covers a long time period and all subsectors ${ }^{2}$ of a market that is representative of many insurance markets in terms of development and penetration. ${ }^{3}$ The dataset thus provides an opportunity to compare and cross-check findings from other countries, across different time periods, and across different subsectors. ${ }^{4}$ Second, the data allows us to investigate the internationalization strategies of insurance companies, an issue of high interest in the business and economics literature, but one that has not to date been the focus of efficiency studies in the insurance sector. The results are useful for academ-

1 A number of cross-country comparisons include Switzerland, but none take a detailed look at the Swiss situation. For example, there is no analysis of efficiency determinants in the Swiss insurance market. Moreover, the existing empirical results for Switzerland are very mixed, i.e., low, average, and high efficiencies are observed, providing no clear indication of productivity development in the Swiss insurance market. Thus, one of the goals of this paper is to provide clearer insight into the productivity situation in Switzerland. In OnlineAppendix A we summarize the extant empirical evidence for Switzerland.

2 On average, efficiency studies in the insurance sector analyze a time period of seven years (see Eling and Luhnen, 2010a); we consider a time period of 17 years. About $67 \%$ of all efficiency studies only look at life, non-life, or specifically at property/casualty (Eling and Luhnen, 2010a); only one study looks at reinsurance separately (Cummins and Weiss, 2002). We analyze all these subsectors individually.

3 According to Swiss Re (2013), the Swiss insurance market ranks seventh in Europe (17 ${ }^{\text {th }}$ in the world), with premium volume of USD 61 billion in 2012. Moreover, in 2012 it ranked first regarding insurance density in Europe (second in the world), with USD 7,604 premiums per capita, and fifth regarding insurance penetration in Europe (13 ${ }^{\text {th }}$ in the world), with premiums to GDP of $9.63 \%$ (see AXCO, 2013).

4 To our knowledge, we are the first to systematically test the robustness of the efficiency results across subperiods (before the first crisis, i.e., 1997-2001, between the two crises, i.e., 2002-2007, and for 2008-2013) and across all subsectors of the industry. In addition, we also distinguish our work from the existing literature with a systematic analysis of nonlinear relationships and interaction effects, all of which provide useful insight into the nature of efficiency in the insurance sector. We thus contribute to the growing number of innovative DEA applications, e.g., the inclusion of uncontrollable variables (see Yang and Pollitt, 2009; Huang and Eling, 2013), two-stage bootstrapping procedures (see Barros et al., 2010), relational two-stage DEA modeling (see Kao and Hwang, 2008, 2014), and cross-frontier analysis (see Biener and Eling, 2012). 
ics, insurance company managers, regulators, and policymakers seeking to better understand market structure and firm performance.

Our results show best practice technology improvements for Swiss property/casualty $(\mathrm{p} / \mathrm{c})$ and reinsurance firms, whereas for life insurance we observe an overall productivity decrease. Our findings suggest that the internationalization of the Swiss insurance business has a positive impact on insurer efficiency, although this effect depends on size and specialization. The analysis of interactions and nonlinear effects shows that being either a small specialist or a large diversified company is optimal from an efficiency point of view, while mid-size companies have disadvantages. Moreover, we provide a robust confirmation of findings from other efficiency studies. $^{5}$

The remainder of this article is structured as follows. In Section 2 we review the relevant literature on efficiency measurement and develop our hypotheses. The methodology and data are presented in Section 3. In Section 4, we discuss the empirical results, separately for life, $\mathrm{p} / \mathrm{c}$, and reinsurance. Section 5 concludes.

\section{Literature Review and Hypotheses Development}

Our analysis of efficiency and productivity development takes place in four stages. We first determine cost, technical, allocative, scale, and revenue efficiency levels, then analyze total factor productivity (TFP) changes, and determine drivers of efficiency. This approach allows us to test eight hypotheses, seven of which are "classics" in the insurance literature (see Table 1). International diversification, however, has not yet been analyzed in the efficiency literature. ${ }^{6}$ Finally, we conduct additional tests to check the robustness of our results across subperiods and subsectors, and for nonlinear relationships and interactions. In the following we first briefly summarize the theoretical background of each hypothesis, then the extant empirical evidence, and finally_-based on both theory and empirical evidence-formulate the direction of the hypothesis for this paper.

5 That is, for different subsectors and across a long time period we find that increasing the size of operation increases efficiency in life and p/c insurance (e.g., in line with Cummins and Zi, 1998). On organizational form, we reject the expense preference hypothesis (e.g., in line with Eling and Luhnen, 2010b, or Biener and Eling, 2012). We document that high debt ratios are detrimental for efficiency (e.g., in line with Luhnen, 2009).

6 There are a few papers that analyze the internationalization strategies of insurance companies, but not by means of efficiency methods. Altuntas and Gößmann (2012) investigate the effect of internationalization on home market performance using survey data and financial statement data from German insurance groups with property/liability business and find that greater internationalization is positively correlated with home market return on assets. Berry-Stölzle et al. (2010) analyze business strategies for insurers entering and growing in emerging markets and find that successful strategies involve a high growth rate, increased size, and more emphasis on life insurance. Moreover, lower financial leverage and mutual organizational form are associated with better performance. All these effects are also measured by our analysis. 
Table 1 Hypotheses and Extant Literature

\begin{tabular}{|c|c|c|}
\hline Hypothesis & Specification & Extant Literature \\
\hline $\begin{array}{l}\text { H1: Development of } \\
\text { productivity and effi- } \\
\text { ciency over time }\end{array}$ & $\begin{array}{l}\text { Productivity and efficiency in the Swiss insur- } \\
\text { ance market increased from 1997-2013. }\end{array}$ & $\begin{array}{l}\text { Donni and Fecher (1997); Luhnen } \\
\text { (2009); Bertoni and Croce (2011) }\end{array}$ \\
\hline $\begin{array}{l}\text { H2: International } \\
\text { diversification }\end{array}$ & $\begin{array}{l}\text { Positive relationship between the level of } \\
\text { international diversification and efficiency. }\end{array}$ & Not yet analyzed in efficiency literature \\
\hline $\begin{array}{l}\text { H3: Size and econo- } \\
\text { mies of scale }\end{array}$ & $\begin{array}{l}\text { (a) Positive relationship between firm size and } \\
\text { efficiency; (b) Small- and medium-sized in- } \\
\text { surers operate under IRS, but large firms } \\
\text { mostly operate under DRS or CRS. }\end{array}$ & $\begin{array}{l}\text { Yuengert (1993); Cummins and Zi } \\
\text { (1998); Luhnen (2009); Eling and } \\
\text { Luhnen (2010b); Cummins and Xie } \\
\text { (2013) }\end{array}$ \\
\hline $\begin{array}{l}\text { H4: Specialization } \\
\text { and economies of } \\
\text { scope }\end{array}$ & $\begin{array}{l}\text { Specialized insurers are more efficient than } \\
\text { diversified insurers (strategic focus vs. con- } \\
\text { glomeration). }\end{array}$ & $\begin{array}{l}\text { Rai (1996); Berger et al. (2000); Cum- } \\
\text { mins et al. (2010) }\end{array}$ \\
\hline $\begin{array}{l}\text { H5: Organizational } \\
\text { form }\end{array}$ & $\begin{array}{l}\text { Stock insurers are more efficient than mutual } \\
\text { insurers. }\end{array}$ & $\begin{array}{l}\text { Cummins et al. (1999b); Diboky and } \\
\text { Ubl (2007); Erhemjamts and Leverty } \\
\text { (2010) }\end{array}$ \\
\hline H6: Leverage & $\begin{array}{l}\text { Negative relationship between leverage and } \\
\text { efficiency. }\end{array}$ & $\begin{array}{l}\text { Cummins and Nini (2002); Luhnen } \\
\text { (2009); Eling and Luhnen (2010b) }\end{array}$ \\
\hline H7: Premium growth & $\begin{array}{l}\text { Negative relationship between premium } \\
\text { growth and efficiency. }\end{array}$ & Luhnen (2009) \\
\hline H8: Company age & $\begin{array}{l}\text { Negative relationship between company age } \\
\text { and efficiency. }\end{array}$ & $\begin{array}{l}\text { Hussels and Ward (2007); Biener and } \\
\text { Eling (2011) }\end{array}$ \\
\hline
\end{tabular}

\section{Development of Productivity and Efficiency over Time}

Deregulation and internationalization of the financial services industry, in conjunction with widespread economic changes such as low interest rates, have created significant competitive pressure for Swiss insurers. More competitive markets have forced the exit of those firms not able to adapt to state-of-the-art technology, especially also because bad underwriting can no longer be compensated by high capital market returns. The observed changes in the last 20 years thus give reason to expect an increase in both productivity and efficiency (i.e., average productivity relative to the best firms in the industry).

Productivity changes over time for the Swiss market are analyzed by Donni and Fecher (1997) in a cross-country sample. Small improvements of $+1.00 \%$ p.a. for Switzerland are found over the period 1983-1991, while the sample's average annual productivity change amounts to $+5.50 \%$ p.a. over those years. The Swiss improvement is the smallest among all analyzed countries. The authors indicate that the improvement is mostly due to best practice technology progress. Focusing on productivity growth in five European insurance markets (Germany, France, Italy, Spain, and the United Kingdom), Bertoni and Croce (2011) investigate the main causes of productivity changes in life insurance for 1997-2004. Overall, they observe a significant TFP increase of, on average, $6.71 \%$ p.a. that is mostly due to best practice technology progress (on average $+6.67 \%$ p.a.) and only partly accounted for by technical adoption (on average $+0.04 \%$ p.a.). These authors, too, indicate that, in the observed countries, more technical progress occurred in the best practices firms, whereas the average insurer 
was not able to catch up. ${ }^{7}$ Following our theoretic line of reasoning and the existing empirical results, we expect that (Hypothesis H1) efficiency and productivity in the Swiss insurance market will have increased over the sample period 1997-2013. From a theoretical point of view one might expect the productivity increase to be driven by best practice adoption (that is less productive companies either improve productivity or leave the market), but the empirical literature for Europe indicates that improvements are more driven by technology progress.

\section{International Diversification and Efficiency}

The European insurance market was deregulated in 1994, with the main purpose being to create a single insurance market in the European Union and thus improve the industry's competitiveness and efficiency. Opening the market increased both competition within countries and cross-border activity. ${ }^{8}$ Switzerland is integrated into the European environment via bilateral agreements with the European Union. The resulting easier access to new markets provides significant expansion opportunities, especially for firms from countries with superior insurance market performance, whereas, and at the same time, competition from foreign firms in home markets requires more effort to retain competitive advantage. Numerous Swiss insurers are active outside Switzerland, to such an extent that $67 \%$ of Swiss premium volume is earned abroad (see Swiss Insurance Association, 2014); likewise, large international insurers have branches in Switzerland. Concurrently, there are several successful firms that exclusively serve the Swiss market. Switzerland is thus an interesting case for an analysis of the relationship between international diversification and efficiency in insurance markets.

International diversification is extensively researched in the strategic management and international business literature (see, e.g., Capar and Kotabe, 2003; Hitt et al., 2006). From a theoretical standpoint, international diversification is driven by economies of scale, access to new resources, average cost reduction, extension of innovative capabilities, knowledge acquisition, location advantages, and access to foreign markets (see Hitt et al., 2006), all of which imply that there should be a positive relationship between international diversification and firm per-

7 Other studies examine the development of efficiency and productivity for other European markets such as Germany and the United Kingdom, and the U.S. market. For the German market, Luhnen (2009) finds an increase of productivity in the German property/liability market of about $8.20 \%$ over the period 1995-2006. The analysis shows that technological progress $(+7.90 \%)$ is the main driver of this development. Hussels and Ward (2007) analyze German and U.K. life insurers for the period 1991-2002 and find small TFP changes over the whole period $(+2.60 \%$ for Germany, $-1.90 \%$ for the United Kingdom), which again are mainly accounted for by technical progress (Germany), and negative technical efficiency change (United Kingdom). Many other markets have been studied with regard to their TFP improvements for several time horizons, most of which find moderate productivity increase over time (see Fecher et al., 1993 for France; Cummins et al., 1996 for Italy; Mahlberg and Url, 2003 and Ennsfellner et al., 2004 for Austria; Barros et al., 2005 for Portugal; Cummins and Rubio-Misas, 2006 for Spain; Bikker and van Leuvensteijn, 2008 for the Netherlands; and Cummins and Xie, 2008 for the United States).

8 When analyzing efficiency development after 1994, several studies document that the deregulation influenced efficiency of European insurers. See, e.g., Cummins and Rubio-Misas (2006), Hussels and Ward (2007), Davutyan and Klumpes (2008), Bertoni and Croce (2011), and Vencappa et al. (2013). 
formance. However, complexity and cost of coordination, especially for large foreign operations, and cultural differences between the home and the foreign markets (the so-called liability of foreignness) are viewed as major barriers to successful international diversification (see Zaheer, 1995; Hitt et al., 1997, 2006). These diverse theories, on how international diversification influences firm performance, are reflected in empirical work (see, e.g., Hitt et al., 2006, for a review of the empirical literature). The conflicting findings of this research have resulted in the development of alternative models that incorporate the costs as well as the benefits of international diversification, for example, assuming u-shaped (see, e.g., Capar and Kotabe, 2003; Ruigrok and Wagner, 2003), inverse u-shaped (see, e.g., Hitt et al., 1997; Kotabe et al., 2002), and s-shaped (see, e.g., Lu and Beamish, 2004) relationships. There is no research on how international diversification impacts efficiency in insurance markets. The only study that is somewhat related (Altuntas and Gößmann, 2012), although it focuses on return on assets (not efficiency), finds a positive impact of German insurers' international diversification on home market performance. ${ }^{9}$ Based on this first piece of evidence, we expect (Hypothesis H2) a positive relationship between the level of international diversification and insurer efficiency. Note that the discussion of internationalization in this paper is limited to life and $\mathrm{p} / \mathrm{c}$ insurers. The business model of reinsurance is to diversify risks globally, which is why every reinsurer per se is internationally diversified; we thus have no variations regarding the degree of internationalization across the reinsurance companies.

Size, Economies of Scale and Efficiency

Most studies argue that there is a positive relation between size and efficiency, explained by the fact that large insurers have significant scale advantages. Scale advantages result from average per unit output cost reductions when the volume of output increases. The most frequently discussed source of scale economies is the spreading of a firm's fixed production costs, such as computer systems and financial capital, over a larger volume of output. Similarly, scale economies may arise from the learning effects gained by managers operating at larger scale. In addition, in the insurance sector it is usually assumed that a larger scale of operation reduces income volatility, since the pooling of risks works better the larger the risk pool (see Cummins and Rubio-Misas, 2006).

Many studies find results in line with the theoretical predictions of a positive relationship between size and efficiency (see, e.g., Cummins and Zi, 1998; Luhnen, 2009; Eling and Luhnen, 2010b). However, some studies argue that the very largest firms suffer from diseconomies of

9 A study by Katrishen and Scordis (1998) focuses on the impact of international diversification on achieving economies of scale in a cross-country study for the years 1985-1992. The authors find decreasing economies of scale with increasing international diversification. Another work of interest in relation to ours is Buch et al. (2014), who discuss productivity and internationalization decisions in the banking sector. 
scale (e.g., due to complexity) so that they are not as efficient as middle-sized insurers (see, e.g., Fenn et al., 2008). Diacon et al. (2002) find, however, that large and small insurers are more (technically) efficient than middle-sized insurers, indicating a u-shape of efficiency values. While Yuengert (1993) concludes that size and efficiency are statistically unrelated, Zanghieri (2008) states that there is a nonlinear relationship between size and efficiency. For life and non-life insurance he shows concave relations between size and cost/profit efficiency (curvilinear and inverted u-shape). The only study including the Swiss market finds that a group of large Swiss insurers is less efficient than a group of small ones (see Rai, 1996), although for each size group, the author observes a positive relationship between size and efficiency (overall a nonlinear relation). Until now, no unique relationship between firm size and efficiency has been identified. We follow the economic rationale and the most widespread empirical finding in the insurance efficiency literature and expect (Hypothesis H3(a)) a positive relation between firm size and efficiency.

Whereas an analysis of size and its effect on efficiency is informative about the level of efficiency relative to the size of operation, scale economies indicate whether efficiency differences result from a firm being too big or too small or whether an increase in operational size is likely to increase or decrease efficiency. In general, there are three types of scale economies: (1) firms not operating at optimal scale and potentially generating disproportionately high additional returns by increasing the size of operations (increasing returns to scale; IRS), (2) firms not operating at optimal scale and potentially generating disproportionately low additional returns by increasing the size of operations (decreasing returns to scale; DRS), and (3) firms generating proportional additional returns by increasing the size of operations (constant returns to scale; CRS). This pattern occurs because, while small firms can benefit from average cost reductions with increasing size, complexity of operation outweighs those advantages when firms become too large.

Most empirical studies find that smaller insurance firms operate under IRS, while larger firms operate under DRS and some under CRS. ${ }^{10}$ We assume the same will be true for the Swiss insurance industry and thus expect that (Hypothesis H3(b)) small and medium-sized insurers are operating under IRS, but that large firms mostly operate under DRS or CRS. A confirmation of these expectations will have important implications for managers, regulators, and poli-

10 Yuengert (1993) finds increasing returns to scale for U.S. life firms with up to US\$15 billion in assets, whereas Cummins and Zi (1998) find these only for firms with up to US\$1 billion in assets. For U.S. property/liability firms, increasing returns to scale are documented up to US\$137 million in assets. See also Fecher et al. (1991) for France, Hardwick (1997) for the United Kingdom, Hwang and Gao (2005) for Ireland, Cummins and Rubio-Misas (2006) for Spain, Qiu and Chen (2006) for China, and Luhnen (2009) for the German property/liability industry. 
cymakers because it will provide justification for mergers among small and medium-size insurers, but not for mergers among large insurers.

\section{Economies of Scope and Efficiency}

Another factor that is analyzed, especially in the M\&A context, is economies of scope. In the context of efficiency, a central question is whether a firm benefits more from specializing in one or a limited set of products, or from a broad diversification of the product portfolio. The two main hypotheses discussed in literature are the conglomeration hypothesis and the strategic focus hypothesis. The conglomeration hypothesis states that firms can take advantage of cost and revenue scope economies by operating in several business lines or offering a multitude of different products, resulting in superior efficiency compared to specialized firms. In contrast, the strategic focus hypothesis claims that specialized insurers generate superior efficiency by focusing on their core business where they exhibit competitive advantages.

Evidence from the insurance literature is again not consistent. For example, Meador et al. (2000) find support for the conglomeration hypothesis from the U.S. life market for the period 1990-1995. Luhnen (2009) and Eling and Luhnen (2010b) observe that interacting in different lines of business is not always superior to focusing on core business activities. According to Cummins et al. (2010), strategic focus is superior to conglomeration in the insurance industry. Berger et al. (2000) note that the conglomeration hypothesis dominates for some types of financial services (i.e., larger insurers with emphasis on personal lines and vertically integrated distribution systems) and the strategic focus hypothesis dominates for other types (i.e., smaller insurers with emphasis on commercial lines and nonintegrated distribution systems). Berry-Stölzle et al. (2013) confirm that the diversification-performance relationship for insurance companies depends on company size. This may explain the empirical puzzle of why generalists and specialists both appear to be competitively viable in the long run. The only Swiss-specific result in this area is provided by Rai (1996), who states that specialized insurers in Switzerland are more efficient than diversified insurance firms. This is in line with the strategic focus hypothesis and leads us to expect that (Hypothesis H4) specialized insurers are more efficient than diversified insurers (strategic focus hypothesis). In the empirical part (Section 4.4.3), we interact specialization and size in order to also test the coexistence prediction by Berger et al. (2000).

\section{Organizational Form and Efficiency}

There are two hypotheses about the relationship between organizational form and insurer efficiency: the expense preference hypothesis (Mester, 1991) and the efficient structure hypothesis (Cummins et al., 2004). Mester (1991) argues that agency conflicts in mutual firms result in efficiency losses, for example, due to higher perquisite consumption by mutual managers. 
Thus, the expense preference hypothesis is that mutual insurers are less efficient than stock insurers. In contrast, the efficient structure hypothesis is that mutual and stock insurers use different technologies and supply separate markets and that each has a competitive advantage in producing its outputs. It is argued that mutual firms are more efficient in lines of business with relatively low managerial discretion, while stocks are more successful in lines where managers need more discretion, such as complex commercial coverage and international operations (Cummins and Weiss, 2013). Also differences in maturity and access to capital can be used to justify the efficient structure hypothesis.

Empirical support for both hypotheses has been found. For the expense preference hypothesis, see, for example, Cummins et al. (1999a) and Erhemjamts and Leverty (2010) for the U.S. market, and Diboky and Ubl (2007) for the German market. However, the expense preference hypothesis was rejected in cross-country studies by Eling and Luhnen (2010b) and Biener and Eling (2012). Evidence in support of the efficient structure hypothesis is found in Cummins et al. (1999b) for the United States, in Diacon et al. (2002) for European life insurers, and in Berry-Stölzle et al. (2009) for the German market. Greene and Segal (2004) observe no significant relationship between efficiency and organizational form for the U.S. life insurance market, thus not providing evidence for either hypothesis. In this paper we empirically test the expense preference hypothesis and refer to the literature for the more complex tests of the efficient structure hypothesis. For the expense preference hypothesis we follow the theoretical reasoning and expect that stocks are more (cost) efficient than mutuals (Hypothesis H5).

\section{Leverage and Efficiency}

Risk-based capital standards, such as the Swiss Solvency Test, often lead to increases in the required capital compared to simple ratio-based capital schemes. The increased security level associated with higher equity capital holdings of insurance firms comes at the expense of costly equity capital. ${ }^{11}$ Because equity capital is one of the inputs in efficiency measurement, an increase in equity, reflected in a decrease of leverage ratios (i.e., debt to asset ratio), ceteris paribus leads to a reduction in productivity; if the increase in equity applies to the entire industry, however, the impact on efficiency is not trivial. ${ }^{12}$ Moreover, the argument could be made that in the long run, increased security levels will be reflected in an increased volume of premiums because policyholders value low levels of insolvency risk (see, e.g., Epermanis and Harrington, 2006). Based on the economic argumentation, we could support both directions.

11 The interaction with other risk management instruments needs to be mentioned here. Higher required capital also can be accounted for by changes in reinsurance, asset allocation, or underwriting strategy. In our analysis we control for such differences since these different strategies impact both inputs and outputs. For example, with more reinsurance, incurred losses are lower and less equity capital is needed. 
Cummins and Nini (2002) analyze capitalization of the U.S. property/liability (p/l) insurance industry for the period 1993-1998 and find that most insurers are significantly over-utilizing equity capital. An over-utilization of equity capital translates to significant revenue and cost of capital penalties, resulting in efficiency losses. In a study of the German $p / 1$ market for 1995-2006, Luhnen (2009) finds evidence of a positive relationship between leverage (his definition is equity to assets, which is sometimes discussed under the term "solvency", see, e.g., Eling and Luhnen, 2010b) and efficiency. The empirical evidence thus does not point to a definite trend in either direction. Given our overlap in sample period and product portfolio with Luhnen (2009), we expect that (Hypothesis Ho) the relationship between leverage (debt to assets ratio) and efficiency is negative for the Swiss sample.

\section{Premium Growth and Efficiency}

Many factors outside of management control have been identified as significant drivers of premium volume, including changes in regulation, general economic conditions, and market competition (see, e.g., Enz, 2000). But other aspects, such as financial strength ratings and reputation, are more influenced by management's strategic decisions. Growth in premiums might also be driven by higher operating expenses resulting from marketing efforts. In addition, if insurers massively increase premium volume, proper underwriting may well be abandoned in the process, leading to increased exposure to adverse selection. Underwriting discipline thus might affect efficiency (see, e.g., Epermanis and Harrington, 2006).

The only empirical study analyzing the relationship between premium growth and efficiency is Luhnen (2009). This study of German p/l insurers documents a negative impact of premium growth on efficiency. Based on the economic rationale and in line with this first empirical evidence, we expect (Hypothesis H7) a negative relationship between premium growth and efficiency in Switzerland.

\section{Company Age and Efficiency}

There are two opposing arguments regarding the impact of age on efficiency. On the one hand, the long-term persistence of a firm in a given market might indicate its ability to successfully adapt its technology to changing market conditions, thus suggesting above-average efficiency and productivity. Firms with a long history are also likely to be more well-known and to enjoy a good reputation. On the other hand, relatively new firms might be more innovative in the use of state-of-the-art production technology, signifying competitive and efficiency advantages for "young" firms.

12 If, for example, a proportional loading is added on the existing equity capital (e.g., every insurer has to hold $10 \%$ more equity), then efficiency remains unchanged. If a fixed loading is added (e.g., every insurer has to hold 1 million more equity), then efficiency could either increase or decrease. 
Both Hussels and Ward (2007) for the German and U.K. life insurance markets and Biener and Eling (2011) for the microinsurance market find that older firms are less efficient than younger ones. Thus, at least for the countries analyzed to date, the innovation argument seems to outweigh the adaption ability and reputation argument such that we expect (Hypothesis H8) that there will be a negative relation between company age and efficiency in the Swiss insurance industry.

\section{Methodology and Data}

\subsection{Methodology}

We use the input-oriented data envelopment analysis (DEA) with constant (CRS) and variable returns to scales (VRS) to approximate "best practice" production, cost, and allocative frontiers, and the output-oriented DEA with CRS and VRS to compute revenue frontiers. To robustly estimate the efficient frontiers in the first stage, we rely on the bootstrap approach introduced by Simar and Wilson (2000) which takes into account the sensitivity of efficiency measures to sampling variation and estimates bias-corrected DEA efficiency scores. We then apply second-stage regressions to make inferences about interactions of efficiency estimates and a set of covariates. We estimate sector-specific efficient frontiers separately as opposed to using a pooled frontier for the whole Swiss insurance market.

To analyze the development of efficiency and productivity over time, we use the Malmquist index of total factor productivity (TFP) (see Caves et al., 1982) and decompose TFP into its principal sources: technical change and technical efficiency change. Technical change represents changes in production technology from one period to another and thus describes shifts in the best practice production frontier. Technical efficiency change concentrates on changes in a firm's distance from the best practice frontier from one period to another. Technical efficiency change can be separated into pure technical efficiency change (measured relative to the VRS frontier) and scale efficiency change (which analyzes differences in distance of VRS to CRS frontier). As for the general efficiency estimates, one can use input- and output-oriented models; for the sake of consistency, we estimate input-oriented TFP. In this context we also incorporate the robust estimation of the Malmquist indices by means of a bootstrap approach as in Simar and Wilson (1999).

To identify drivers of firm efficiency we analyze the impact of firm-specific determinants on efficiency within a second-stage regression. Simar and Wilson (2011) compare the two statistical models for which the second-stage regression is well defined and meaningful: truncated regression and ordinary least squares (OLS). They point out that second-stage OLS estimation is consistent only under very strict conditions, which are not satisfied by our data. For this reason we use the two-stage double bootstrap truncated regression procedure suggested by 
Simar and Wilson (2007), which provides consistent second-stage estimations. ${ }^{13}$ In the specifications of the bootstrap algorithm, efficiency scores that have support between 1 and infinity (i.e., 1 defines an efficient firm) are used, which is why we transform the efficiency scores, which are bounded between 0 and 1 , by 1 /efficiency, in a first step. This changes the interpretation of the regression coefficients (i.e., negative coefficients imply an increase in efficiency, positive coefficients a decrease). The model that is estimated has a left truncation point at 1 and is specified as follows:

$$
1 / \text { efficiency }_{i, t}=\beta X_{i, t}+\gamma T_{t}+\varepsilon_{i, t},
$$

where efficiency $y_{i, t}$ represents the efficiency score (i.e., technical, cost, or revenue) of firm $i$ at time $t$ estimated in the first stage, $X_{i, t}$ consists of seven firm-specific determinants, and $T_{t}$ is a vector of year indicator variables to control for time effects; $\beta$ and $\gamma$ are the estimated parameter vectors. The seven firm-specific characteristics measure international diversification (i.e., ratio of premiums written abroad to total premiums written), firm size (i.e., natural logarithm of total assets), specialization (i.e., Herfindahl Index of written premiums over line of businesses), organizational form (i.e., stock vs. mutual), leverage (i.e., ratio of debt to total assets), premium growth (i.e., year-to-year changes in premiums), and company age (i.e., natural logarithm of age). ${ }^{14}$

\subsection{Data}

Our data originate from the Swiss regulator FINMA and have not yet been employed in the literature. All Swiss insurers are required to file their annual reports with the regulator so that we have complete market coverage. Our dataset consists of life, $p / c$, and reinsurance financial statements reported for the period 1997-2013 and contains information for all insurers operating in Switzerland.

There is widespread agreement in the insurance literature in regard to the choice of inputs, outputs, and prices (see Eling and Luhnen, 2010a; Cummins and Weiss, 2013). According to the value-added approach (see, e.g., Grace and Timme, 1992; Berger et al., 2000; Leverty and Grace, 2010), insurance firms fulfill three major functions: risk pooling/bearing, financial services, and intermediation. As a proxy for the risk pooling/bearing and financial services functions, we use the present value of losses paid plus additions to reserves (i.e., real incurred

13 As a robustness test, we also estimated an OLS model. Our results are consistent under both approaches with only two exceptions. The OLS results are available from the authors upon request.

14 Another covariate that has not been analyzed extensively in frontier efficiency analyses is market share. We exclude this variable from our analysis because it is highly correlated with firm size (correlation coefficient $=$ 0.986 for life, 0.825 for $\mathrm{p} / \mathrm{c}, 0.931$ for reinsurance). Other variables included in additional tests, but not shown here, are market-specific variables (e.g., interest rate, concentration (Herfindahl Index of the market) and inflation). These firm-invariant characteristics cannot be included together with the time effects. 
losses) for $\mathrm{p} / \mathrm{c}$ and reinsurance and paid benefits plus additions to reserves for life insurers. In the literature, premiums are sometimes used instead of real incurred losses to proxy risk pooling/bearing and financial services. However, the use of premiums as a proxy is subject to criticism since premiums already represent price times quantity of the output and not just output (see Yuengert, 1993), which is why we focus on paid benefits and incurred losses. The output variable that best proxies the intermediation function is the real value of total investments. Insurance firms receive funds from their customers and invest them until the firm is required to pay benefits or the funds are withdrawn by the policyholder in the case of asset accumulation products (see, e.g., Cummins and Weiss, 2013).

The price for the output real incurred loss is generally defined as the difference of net premiums earned and the output value (paid benefits/present value of losses plus additions to reserves) divided by this output value (see, e.g., Leverty and Grace, 2010; Grace et al., 2014). Since earned premiums represent an estimate of expected losses, this ratio shows the relative markup between the expected and actual losses. To avoid negative ratios, we average the firm-specific values to a market average per years as it is usually done with input prices (see, e.g., Cummins and Rubio-Misas, 2006). For the price of the intermediation output (total investments) we use the expected rate of return of these investments as a proxy. This is given by the weighted average of returns for debt and equity investments weighted by the proportion of assets invested in debt securities and stocks. The rate of return for debt securities is defined by the actual investment income without dividends divided by the total of debt instruments (see Cummins and Weiss, 2013; the data is again taken from the Swiss regulator). The rate of return for the equity investments is given by seven-year averages of yearly return rates of the MSCI World (the data is taken from Thomson Reuters Datastream). As for the real incurred loss price, we again average the firm-specific values on a market level to avoid negative returns.

For the input factors, the literature suggests the use of labor, business services, and capital (see, e.g., Cummins et al., 2004; Eling and Luhnen, 2010a). However, because of limited data availability, common practice is to aggregate labor and business services into one category labeled "operating expenses" (including commissions; see, e.g., Ennsfellner et al., 2004; Fenn et al., 2008). According to Cummins and Weiss (2013), operating expenses are mostly labor related (i.e., the largest components are employee salaries and commissions), and thus one should approximate the price for operating expenses by the price of labor. As price of labor we use an annual wage variable for the Swiss insurance sector, which we obtain from the Swiss Federal Statistical Office. The input capital is subdivided into debt and equity capital. For the price of debt capital we use 10-year average returns of Swiss confederation bonds 
(obtained from the Swiss National Bank); similarly, as a proxy for the price of equity capital we use seven-year averages of yearly rates of return of the Swiss Market Index (SMI) (returns collected from Datastream). This approach avoids the problem of negative returns and is used in other studies (e.g., Cummins et al., 2004; Diboky and Ubl, 2007; Luhnen, 2009). ${ }^{15}$

For our analysis we have an unbalanced panel dataset for the entire Swiss insurance industry covering the period 1997-2013 that is separated into life, p/c, and reinsurance. The advantage of using an unbalanced panel is that it allows the inclusion of firms entering and leaving the market in the observation period. From our initial dataset we exclude all observations for which one input or output is non-positive since DEA requires inputs and outputs to be nonnegative. ${ }^{16}$ Additionally, we exclude outliers based on the cloud methodology (see, e.g., Andrews and Pregibon, 1978; Wilson, 1993). Finally, to account for comparability over time, we deflate all inputs and outputs by the Swiss consumer price index (obtained from the Swiss Federal Statistical Office) to the base year 2010 (see, e.g., Cummins and Zi, 1998). Our final dataset consists of 34 life, $86 \mathrm{p} / \mathrm{c}$, and 101 reinsurers. ${ }^{17}$ The relatively large number of reinsurance firms is due to the numerous new market entrants in the analyzed period. Summary statistics of inputs/outputs and prices are given in Table 2.

15 In principal every insurer should have own prices for debt and equity capital, which depend on its capital structure and portfolio risks. Cummins and Weiss (2013) discuss some alternative price measures. As a robustness test, we also estimated all models with firm-specific input and output prices. Results are available from the authors upon request. Those findings confirm the observations in Section 4.

16 An exception is output one (real incurred losses). If real incurred losses are negative, this can be due to a negative amount of current losses/benefits paid (which is impossible, and in which case we excluded the observation), or to a negative amount of additions to reserve (which is possible) that was higher than the current losses paid. In the latter case, we shifted outputs for the whole sample such that they are non-negative. Given translation invariance of the model, this approach is possible (see, e.g., Pastor, 1996). However, this translation invariance in our implementation is just given for outputs (if input-oriented DEA model is used), which is why we checked revenue efficiency (computed by an output-oriented model and thus by theory not translation invariant), and could not identify significant changes.

17 We cover about $100 \%$ of the life, $96 \%$ of the $\mathrm{p} / \mathrm{c}$, and $67 \%$ of the reinsurance market in 1997 , measured by total written gross premiums. We obtained the total premium volume in the market from the FINMA website. This number also included all premiums earned in Switzerland by non-Swiss insurers. Since many foreign reinsurance firms have business in Switzerland this is one reason for the relatively small cover of our data in reinsurance. The second reason is that the total premium volume also included reinsurance premiums that primary insurers earned and we have just pure reinsurance firms (no direct insurers) in our sample for reinsurance. 
Table 2 Summary Statistics

\begin{tabular}{|c|c|c|c|c|c|c|c|c|c|c|}
\hline \multicolumn{2}{|c|}{ Inputs } & \multicolumn{4}{|c|}{ Input prices } & \multicolumn{2}{|c|}{ Outputs } & \multicolumn{3}{|c|}{ Output prices } \\
\hline & $\begin{array}{r}\text { Labor and } \\
\text { business } \\
\text { services }\end{array}$ & $\begin{array}{r}\text { Debt } \\
\text { capital }\end{array}$ & $\begin{array}{l}\text { Equity } \\
\text { capital }\end{array}$ & $\begin{array}{r}\text { Labor and } \\
\text { business } \\
\text { services }\end{array}$ & $\begin{array}{r}\text { Debt } \\
\text { capital }\end{array}$ & $\begin{array}{l}\text { Equity } \\
\text { capital }\end{array}$ & $\begin{array}{r}\text { Bene- } \\
\text { fits/losses } \\
\text { incurred }\end{array}$ & $\begin{array}{r}\text { Total } \\
\text { invest- } \\
\text { ments }\end{array}$ & $\begin{array}{r}\text { Bene- } \\
\text { fits/losses } \\
\text { incurred }\end{array}$ & $\begin{array}{r}\text { Total } \\
\text { invest- } \\
\text { ments }\end{array}$ \\
\hline Unit & Quantity & $\begin{array}{l}\text { Mio. } \\
\text { CHF }\end{array}$ & $\begin{array}{l}\text { Mio. } \\
\text { CHF }\end{array}$ & $\mathrm{CHF}$ & $\%$ & $\%$ & $\begin{array}{l}\text { Mio. } \\
\text { CHF } \\
\end{array}$ & $\begin{array}{l}\text { Mio. } \\
\text { CHF }\end{array}$ & & $\%$ \\
\hline \multicolumn{11}{|c|}{ Panel A: Life insurance (34 companies, 395 firm-year observations) } \\
\hline Mean & 1,768 & 12,765 & 371 & 85,192 & 2.63 & 9.68 & 2,194 & 12,756 & 1.66 & 15.80 \\
\hline $\begin{array}{l}\text { Std. } \\
\text { Dev. }\end{array}$ & 3,198 & 24,285 & 772 & 7,842 & 0.87 & 8.61 & 3,458 & 24,403 & 2.62 & 6.62 \\
\hline Min. & 2.90 & 4.87 & 2.30 & 74,106 & 0.66 & 0.23 & 113 & 7.90 & 0.52 & 1.48 \\
\hline Max. & 18,783 & 128,118 & 4,670 & 98,904 & 3.88 & 23.03 & 16,893 & 131,500 & 12.11 & 26.49 \\
\hline \multicolumn{11}{|c|}{ Panel B: P/c insurance (86 companies, 1,039 firm-year observations) } \\
\hline Mean & 1,770 & 1,587 & 371 & 86,142 & 2.55 & 8.57 & 473 & 1,806 & 1.68 & 27.88 \\
\hline $\begin{array}{l}\text { Std. } \\
\text { Dev. }\end{array}$ & 7,386 & 7,250 & 1,663 & 7,673 & 0.88 & 8.16 & 1,722 & 8,022 & 2.69 & 3.94 \\
\hline Min. & 0.09 & 0.03 & 0.35 & 74,106 & 0.66 & 0.23 & 25 & 0.19 & 0.52 & 21.23 \\
\hline Max. & 71,878 & 75,198 & 20,461 & 98,904 & 3.88 & 23.03 & 17,225 & 79,134 & 12.11 & 35.54 \\
\hline \multicolumn{11}{|c|}{ Panel C: Reinsurance (101 companies, 779 firm-year observations) } \\
\hline Mean & 1,540 & 1,848 & 428 & 88,347 & 2.36 & 6.30 & 2,242 & 1,733 & 1.56 & 23.95 \\
\hline $\begin{array}{l}\text { Std. } \\
\text { Dev. }\end{array}$ & 7,181 & 9,133 & 2,052 & 7,088 & 0.88 & 6.86 & 1,664 & 8,528 & 2.54 & 5.03 \\
\hline Min. & 0.05 & $<0.01$ & 0.83 & 74,106 & 0.66 & 0.23 & 1.751 & 0.13 & 0.52 & 13.97 \\
\hline Max. & 85,017 & 86,228 & 19,533 & 98,904 & 3.88 & 23.03 & 18,579 & 93,692 & 12.11 & 34.67 \\
\hline
\end{tabular}

\section{Empirical Results}

\subsection{Efficiency Levels}

Table 3 presents the average, bias-corrected efficiency values for cost (CE), technical (TE), allocative (AE), scale (SE), and revenue efficiency (RE). The efficiency levels are relatively high across the different sectors. For example, life insurers' CE ranges between 0.93 and 0.98 , indicating that the average life insurer can improve $\mathrm{CE}$ by about $2-7 \%$ to be fully $\mathrm{CE}{ }^{18}$ Scores for $\mathrm{p} / \mathrm{c}$ and reinsurance are slightly smaller than those for life. For example, the values for $\mathrm{CE}$ in $\mathrm{p} / \mathrm{c}$ range between 0.82 and $0.90,{ }^{19}$ those for reinsurance between 0.81 and $0.89 .{ }^{20}$ Those results, however, do not necessarily indicate that $\mathrm{p} / \mathrm{c}$ and reinsurance firms are less efficient than life firms; it might be that the life insurers are more homogenous.

18 Although, the cross-country studies of Davutyan and Klumpes (2008), Zanghieri (2008), and Eling and Luhnen (2010b) include the Swiss life insurance market, we cannot directly compare their results with our analysis, since their measures are not based on single-country frontiers. Relative to geographically close insurance markets, such as Germany, the Swiss life insurance market exhibits higher efficiency (see, e.g., Trigo-Gamarra and Growitsch, 2010, who find CE between 0.22 and 0.66; see also Hussels and Ward, 2007).

19 Results exist for the p/c market for other countries; however, most of these include reinsurers, which limit the comparability of the results. Other markets exhibit smaller (e.g., Cummins and Xie, 2008 for the United States and Luhnen, 2009 for Germany) or similar (e.g., Berry-Stölzle et al., 2009 for Germany) efficiency values than those found for Switzerland.

20 There is little literature analyzing reinsurance efficiency separately since most studies subsume reinsurance under the non-life category, including the p/c insurance market. The only study we are aware of that investigates efficiency for reinsurers specifically is that of Cummins and Weiss (2002), who use the standard deviation of ROE as input and the mean ROE as output. 
Table 3 DEA Efficiency Levels

\begin{tabular}{|c|c|c|c|c|c|c|c|c|c|c|c|c|c|c|c|c|c|}
\hline & 1997 & 1998 & 1999 & 2000 & 2001 & 2002 & 2003 & 2004 & 2005 & 2006 & 2007 & 2008 & 2009 & 2010 & 2011 & 2012 & 2013 \\
\hline \multicolumn{18}{|c|}{ Panel A: life insurance } \\
\hline No. & 31 & 30 & 30 & 28 & 24 & 21 & 23 & 23 & 22 & 22 & 21 & 20 & 21 & 21 & 20 & 19 & 19 \\
\hline $\mathrm{CE}$ & 0.97 & 0.97 & 0.97 & 0.98 & 0.98 & 0.98 & 0.98 & 0.97 & 0.96 & 0.97 & 0.95 & 0.93 & 0.97 & 0.97 & 0.97 & 0.98 & 0.98 \\
\hline TE & 0.98 & 0.99 & 0.98 & 0.99 & 0.99 & 0.99 & 0.99 & 0.98 & 0.98 & 0.97 & 0.96 & 0.95 & 0.98 & 0.98 & 0.98 & 0.99 & 0.99 \\
\hline $\mathrm{AE}$ & 0.99 & 0.99 & 0.99 & 0.99 & 0.99 & 0.99 & 0.99 & 0.99 & 0.99 & 0.99 & 0.99 & 0.99 & 0.99 & 0.99 & 0.99 & 0.99 & 0.99 \\
\hline $\mathrm{SE}$ & 0.99 & 0.98 & 0.99 & 0.98 & 0.98 & 0.98 & 0.98 & 0.99 & 0.99 & 0.99 & 1.00 & 1.00 & 0.98 & 0.98 & 0.98 & 0.98 & 0.99 \\
\hline RE & 0.93 & 0.95 & 0.97 & 0.99 & 0.99 & 0.98 & 0.96 & 0.98 & 0.95 & 0.97 & 0.96 & 0.92 & 0.97 & 0.97 & 0.96 & 0.98 & 0.97 \\
\hline \multicolumn{18}{|c|}{ Panel B: $p / c$ insurance } \\
\hline No. & 62 & 64 & 62 & 63 & 62 & 64 & 64 & 62 & 63 & 63 & 55 & 62 & 61 & 58 & 58 & 60 & 56 \\
\hline $\mathrm{CE}$ & 0.84 & 0.85 & 0.83 & 0.85 & 0.86 & 0.85 & 0.83 & 0.83 & 0.84 & 0.86 & 0.89 & 0.84 & 0.89 & 0.86 & 0.82 & 0.84 & 0.90 \\
\hline TE & 0.91 & 0.91 & 0.89 & 0.92 & 0.93 & 0.90 & 0.89 & 0.91 & 0.92 & 0.92 & 0.96 & 0.88 & 0.93 & 0.89 & 0.90 & 0.91 & 0.93 \\
\hline $\mathrm{AE}$ & 0.92 & 0.94 & 0.93 & 0.93 & 0.92 & 0.94 & 0.93 & 0.92 & 0.91 & 0.93 & 0.93 & 0.94 & 0.96 & 0.96 & 0.92 & 0.92 & 0.96 \\
\hline SE & 0.96 & 0.96 & 0.97 & 0.96 & 0.95 & 0.96 & 0.97 & 0.96 & 0.95 & 0.97 & 0.96 & 0.95 & 0.94 & 0.96 & 0.91 & 0.93 & 0.95 \\
\hline $\mathrm{RE}$ & 0.94 & 0.94 & 0.90 & 0.92 & 0.92 & 0.88 & 0.81 & 0.89 & 0.90 & 0.90 & 0.91 & 0.86 & 0.94 & 0.91 & 0.92 & 0.93 & 0.94 \\
\hline \multicolumn{18}{|c|}{ Panel C: reinsurance } \\
\hline No. & 24 & 25 & 25 & 33 & 35 & 43 & 42 & 45 & 54 & 56 & 51 & 59 & 59 & 58 & 57 & 56 & 57 \\
\hline $\mathrm{CE}$ & 0.85 & 0.88 & 0.89 & 0.89 & 0.81 & 0.85 & 0.84 & 0.83 & 0.84 & 0.88 & 0.89 & 0.85 & 0.88 & 0.85 & 0.86 & 0.84 & 0.84 \\
\hline TE & 0.94 & 0.93 & 0.95 & 0.95 & 0.89 & 0.92 & 0.90 & 0.88 & 0.90 & 0.93 & 0.94 & 0.91 & 0.92 & 0.89 & 0.91 & 0.90 & 0.89 \\
\hline $\mathrm{AE}$ & 0.91 & 0.94 & 0.93 & 0.94 & 0.91 & 0.92 & 0.93 & 0.95 & 0.93 & 0.95 & 0.94 & 0.93 & 0.96 & 0.95 & 0.94 & 0.93 & 0.93 \\
\hline SE & 0.92 & 0.96 & 0.93 & 0.95 & 0.95 & 0.90 & 0.93 & 0.94 & 0.91 & 0.94 & 0.94 & 0.87 & 0.89 & 0.91 & 0.89 & 0.83 & 0.87 \\
\hline $\mathrm{RE}$ & 0.99 & 0.99 & 0.99 & 0.99 & 0.98 & 0.98 & 0.99 & 0.98 & 0.98 & 0.99 & 0.99 & 0.98 & 0.98 & 0.98 & 0.98 & 0.98 & 0.98 \\
\hline
\end{tabular}

Note: Mean efficiencies estimated with respect to own annual and sector frontiers. CE $=$ cost efficiency, TE $=$ technical efficiency, $\mathrm{AE}=$ allocative efficiency, $\mathrm{SE}=$ scale efficiency, $\mathrm{RE}=$ revenue efficiency.

\subsection{Malmquist Index of Total Factor Productivity}

In Table 4 we measure TFP changes using input-oriented Malmquist productivity indices. We present results for the complete observation period as well as averages across yearly changes. The latter is important because, in an unbalanced panel, the TFP change for the complete observation period will contain only a limited number of observations. The TFP change for life insurance indicates a productivity decline over the complete observation period of about $13 \%$. This is due to a shift in the frontier by a similar amount (technical change of $-13 \%$ ). This negative overall trend is also illustrated by an average (geometric) yearly reduction of about $1 \%$ in both of these values. This result indicates that, over the observation period, Swiss life insurers consistently lost productivity. Moreover, even though best practice firms became less productive, non-efficient firms could not catch up, indicating that the entire life insurance market suffered from this technological regress. We believe these findings illustrate the general difficulties experienced by the life insurance sector in adapting to an increasingly challenging business environment of low interest rates and increased competition from other financial services providers such as banks. While the level of inputs remains largely unchanged, in many cases the output levels decline, for instance due to loss of business to competitors in other industries or due to lower investments. 
Table 4 Malmquist Index of Total Factor Productivity

\begin{tabular}{|c|c|c|c|c|c|c|}
\hline Period & $\begin{array}{l}\text { (Average) no. of } \\
\text { firms }\end{array}$ & $\begin{array}{l}\text { Technical } \\
\text { change }\end{array}$ & $\begin{array}{l}\text { Technical } \\
\text { efficiency } \\
\text { change }\end{array}$ & $\begin{array}{l}\text { Pure technical } \\
\text { efficiency } \\
\text { change }\end{array}$ & $\begin{array}{l}\text { Scale } \\
\text { efficiency } \\
\text { change }\end{array}$ & $\begin{array}{l}\text { Total factor } \\
\text { productivity } \\
\text { change }\end{array}$ \\
\hline \multicolumn{7}{|c|}{ Panel A: life insurance } \\
\hline Arithmetic mean & 22.2 & 0.99 & 1.00 & 1.00 & 1.00 & 0.99 \\
\hline Geometric mean & 22.2 & $0.99 * *$ & 1.00 & 1.00 & 1.00 & $0.99 * *$ \\
\hline $\begin{array}{l}\text { Complete panel: } \\
\text { 1997-2013 }\end{array}$ & 16 & $0.87 *$ & 0.99 & 1.00 & 1.00 & $0.87 *$ \\
\hline \multicolumn{7}{|c|}{ Panel B: $p / c$ insurance } \\
\hline Arithmetic mean & 58.4 & $1.01 * *$ & $1.01 *$ & $1.01 *$ & 1.00 & $1.02 * * *$ \\
\hline Geometric mean & 58.4 & 1.00 & 1.00 & 1.00 & 1.00 & 1.00 \\
\hline $\begin{array}{l}\text { Complete panel: } \\
\text { 1997-2013 }\end{array}$ & 39 & 0.99 & 1.03 & 1.02 & 1.01 & 1.02 \\
\hline \multicolumn{7}{|c|}{ Panel $C$ : reinsurance } \\
\hline Arithmetic mean & 40.5 & $1.02 *$ & $1.01 *$ & 1.01 & $1.01 *$ & $1.04 * *$ \\
\hline Geometric mean & 40.5 & 1.00 & 1.00 & 1.00 & 1.00 & 1.00 \\
\hline $\begin{array}{l}\text { Complete panel: } \\
\text { 1997-2013 }\end{array}$ & 11 & $1.13 *$ & 1.04 & 0.94 & 1.15 & 1.24 \\
\hline
\end{tabular}

Note: Test of significance is based on two-tailed t-test using the bootstrapped Malmquist indices. ${ }^{* * *},{ }^{* *}$, and ${ }^{*}$ indicate significant differences from unity at the $1 \%, 5 \%$, and $10 \%$ level, respectively.

For the $\mathrm{p} / \mathrm{c}$ and reinsurance industry, we find no significant TFP change over the whole period. However, yearly average scores indicate an increase in TFP of about $2 \%(\mathrm{p} / \mathrm{c})$ and $4 \%$ (reinsurance). In both sectors this increase is explained by progress in best practice technology, that is, a positive technical change ( $1 \%$ for $\mathrm{p} / \mathrm{c}$ and $2 \%$ for reinsurance per year), and also by efficiency improvements, indicated by an average yearly technical efficiency increase of $1 \%$ in both sectors. This result is in line with Donni and Fecher (1997), who analyze the whole Swiss market in a cross-country setting from 1983-1991.

Our findings confirm hypothesis $\mathrm{H} 1$ for $\mathrm{p} / \mathrm{c}$ and reinsurance, but not for life insurance. The positive development of technology in the $\mathrm{p} / \mathrm{c}$ and reinsurance sectors (i.e., the development of the best practices firms) is accompanied by a similar technical efficiency change. This implies that despite the industries' progress, insurers on average follow the technological improvements of their peers in the industry, and can even catch up slightly to best practices. The results are in line with other European studies showing that productivity improvements in general result both from technology progress and better technology adoption. ${ }^{21}$

\subsection{Efficiency Determinants}

We present second-stage regression results of the reciprocal technical, cost, and revenue efficiency estimates on seven firm-specific characteristics. Descriptive statistics and correlation characteristics of the covariates are shown in Online-Appendix C. We control for multicollinearity and also analyze potential correlations between the different variables. ${ }^{22}$ The results

21 Luhnen (2009) observes a TFP change of $8.20 \%$ for the German p/l market over a period of 12 years, whereas our results for $\mathrm{p} / \mathrm{c}$ do not show significant productivity progress over the whole sample period. However, Luhnen's TFP improvement and our average 2\% TFP increase per year are similar trends. For life, we find no improvement, whereas Bertoni and Croce (2011) find a significant improvement of 6.71\% p.a. in Europe. Detailed by-year changes in TFP growth are presented in Online-Appendix B.

22 For example, the correlation between size and the level of internationalization is 0.38 (life insurance) and 0.27 ( $\mathrm{p} / \mathrm{c}$ insurance), which does not strike us a serious concern, since the Variance Inflation Factors in OLS 
from the truncated regression model based on the Simar and Wilson (2007) approach are presented in Table 5. Note again that the interpretation of the effects is reversed because of the transformation in the dependent variable. For all models in Table 5and the following analyses, we calculate p-values for each coefficient based on 2,000 bootstrap replications. We define the $\mathrm{p}$-values to be the frequency of bootstrap estimates with the opposite sign as the original coefficient (e.g., if the coefficient is negative in the first run, the p-value for this coefficient is the ratio of non-negative bootstrap estimates to total number of bootstrap estimates computed; see, e.g., Afonso and Aubyn, 2006; and Luhnen, 2009).

Table 5 Truncated Regression Results

\begin{tabular}{|c|c|c|c|c|c|c|c|c|c|c|}
\hline \multirow[b]{2}{*}{ Variable } & \multirow[b]{2}{*}{ Definition } & \multicolumn{3}{|c|}{ life insurance } & \multicolumn{3}{|c|}{$\mathrm{p} / \mathrm{c}$ insurance } & \multicolumn{3}{|c|}{ reinsurance } \\
\hline & & $T E$ & $C E$ & $R E$ & $T E$ & $C E$ & $R E$ & $T E$ & $C E$ & $R E$ \\
\hline $\begin{array}{l}\text { Int'l } \\
\text { diversification }\end{array}$ & $\begin{array}{l}\text { Ratio of premiums written abroad } \\
\text { to total premiums written }\end{array}$ & $\begin{array}{l}-0.86^{* * *} \\
(0.000)\end{array}$ & $\begin{array}{l}-1.59^{* * *} \\
(0.000)\end{array}$ & $\begin{array}{l}-1.53 * * * \\
(0.000)\end{array}$ & $\begin{array}{l}9.70^{* * *} \\
(0.000)\end{array}$ & $\begin{array}{l}11.92^{* *} \\
(0.016)\end{array}$ & $\begin{array}{l}-7.82 * * * \\
(0.000)\end{array}$ & -- & -- & -- \\
\hline Size & $\ln$ (total assets) & $\begin{array}{l}-0.08 * * * \\
(0.000)\end{array}$ & $\begin{array}{l}-0.13 * * * \\
(0.000) \\
\end{array}$ & $\begin{array}{l}-0.07 * * * \\
(0.000) \\
\end{array}$ & $\begin{array}{l}-0.73 * * * \\
(0.002) \\
\end{array}$ & $\begin{array}{l}-1.44 * * * \\
(0.002)\end{array}$ & $\begin{array}{l}-0.52 * * * \\
(0.004) \\
\end{array}$ & $\begin{array}{l}-1.96^{* * *} \\
(0.000) \\
\end{array}$ & $\begin{array}{l}-6.83^{* * *} \\
(0.000) \\
\end{array}$ & $\begin{array}{l}0.07^{* * *} \\
(0.000)\end{array}$ \\
\hline Specialization & $\begin{array}{l}\text { Premiums in line of business } \\
\text { Herfindahl Index }\end{array}$ & $\begin{array}{l}0.18^{*} \\
(0.073)\end{array}$ & $\begin{array}{l}0.00 \\
(0.542)\end{array}$ & $\begin{array}{l}0.21^{* *} \\
(0.016)\end{array}$ & $\begin{array}{l}2.88^{* * *} \\
(0.015)\end{array}$ & $\begin{array}{l}8.41^{* * * *} \\
(0.001)\end{array}$ & $\begin{array}{l}-3.65^{* * *} \\
(0.000)\end{array}$ & $\begin{array}{l}2.11^{*} \\
(0.097)\end{array}$ & $\begin{array}{l}-2.58 \\
(0.226)\end{array}$ & $\begin{array}{l}-0.92^{* * *} \\
(0.000)\end{array}$ \\
\hline Organizational form & Dummy ( $1=$ stock, $0=$ mutual $)$ & $\begin{array}{l}0.69^{* * *} \\
(0.000)\end{array}$ & $\begin{array}{l}1.23^{* * * *} \\
(0.000)\end{array}$ & $\begin{array}{l}1.11^{* * *} \\
(0.000)\end{array}$ & $\begin{array}{l}6.44^{* * * *} \\
(0.000)\end{array}$ & $\begin{array}{l}16.34^{* * *} \\
(0.000)\end{array}$ & $\begin{array}{l}0.11 \\
(0.497)\end{array}$ & -- & -- & -- \\
\hline Leverage & Debt to total assets & $\begin{array}{l}1.32 * * * \\
(0.000)\end{array}$ & $\begin{array}{l}1.88^{* * *} \\
(0.000)\end{array}$ & $\begin{array}{l}1.19^{* * *} \\
(0.000)\end{array}$ & $\begin{array}{l}7.90^{* * * *} \\
(0.001) \\
\end{array}$ & $\begin{array}{l}6.02^{*} \\
(0.098) \\
\end{array}$ & $\begin{array}{l}8.53^{* * *} \\
(0.000) \\
\end{array}$ & $\begin{array}{l}20.78^{* * *} \\
(0.000)\end{array}$ & $\begin{array}{l}90.46^{* * *} \\
(0.000) \\
\end{array}$ & $\begin{array}{l}0.69^{* * *} \\
(0.000)\end{array}$ \\
\hline Premium growth & $\begin{array}{l}\text { Growth rate of total } \\
\text { written premiums }\end{array}$ & $\begin{array}{l}-0.07 \\
(0.222)\end{array}$ & $\begin{array}{l}-0.13 \\
(0.120)\end{array}$ & $\begin{array}{l}-0.17^{* *} \\
(0.011)\end{array}$ & $\begin{array}{l}-3.85^{* * *} \\
(0.007) \\
\end{array}$ & $\begin{array}{l}-2.33 \\
(0.210) \\
\end{array}$ & $\begin{array}{l}1.72^{*} \\
(0.064)\end{array}$ & $\begin{array}{l}-4.59 * * * \\
(0.000)\end{array}$ & $\begin{array}{l}-3.54^{*} \\
(0.055) \\
\end{array}$ & $\begin{array}{l}-0.37^{* * * *} \\
(0.000)\end{array}$ \\
\hline Company age & $\ln$ (company age) & $\begin{array}{l}0.05 \\
(0.118) \\
\end{array}$ & $\begin{array}{l}0.05 \\
(0.160) \\
\end{array}$ & $\begin{array}{l}0.03 \\
(0.187) \\
\end{array}$ & $\begin{array}{l}-3.75^{* * * *} \\
(0.000) \\
\end{array}$ & $\begin{array}{l}-8.47 * * * * \\
(0.000) \\
\end{array}$ & $\begin{array}{l}-2.68^{* * * *} \\
(0.000) \\
\end{array}$ & $\begin{array}{l}3.09^{* *} \\
(0.013) \\
\end{array}$ & $\begin{array}{l}5.50^{* * * *} \\
(0.006) \\
\end{array}$ & $\begin{array}{l}-0.27^{* * * *} \\
(0.000) \\
\end{array}$ \\
\hline \multicolumn{2}{|l|}{ Year dummies } & \multicolumn{3}{|c|}{ included } & \multicolumn{3}{|c|}{ included } & \multicolumn{3}{|c|}{ included } \\
\hline Sigma & & $\begin{array}{l}0.10^{* * * *} \\
(0.000)\end{array}$ & $\begin{array}{l}0.14^{* * * *} \\
(0.000)\end{array}$ & $\begin{array}{l}0.12 * * * \\
(0.000)\end{array}$ & $\begin{array}{l}1.27^{* * *} \\
(0.000) \\
\end{array}$ & $\begin{array}{l}2.45^{* * * *} \\
(0.000)\end{array}$ & $\begin{array}{l}1.10^{* * *} \\
(0.000)\end{array}$ & $\begin{array}{l}2.06^{* * * *} \\
(0.000)\end{array}$ & $\begin{array}{l}3.67^{* * * *} \\
(0.000)\end{array}$ & $\begin{array}{l}0.13^{* * * *} \\
(0.000)\end{array}$ \\
\hline Number of observatio & & 359 & 359 & 359 & 882 & 882 & 882 & 633 & 633 & 633 \\
\hline
\end{tabular}

Note: p-values are presented in parentheses and are estimated as in Afonso and Aubyn (2006) and Luhnen (2009). ${ }^{* * *}, * *$, and $*$ denote the statistical significance level at the $1 \%, 5 \%$, and $10 \%$ level, respectively. TE $=$ technical efficiency, $\mathrm{CE}=$ cost efficiency, and $\mathrm{RE}=$ revenue efficiency.

International Diversification: We measure international diversification by the ratio of foreign premiums to total premiums, which is standard in the strategic management and international business literature (see, e.g., Capar and Kotabe, 2003). Table 5 reveals a positive relationship for all efficiency measures in the life insurance market and $p / c$ insurers' RE. These results confirm our hypothesis. For the other efficiency measures in the $\mathrm{p} / \mathrm{c}$ insurance industry (TE and $\mathrm{CE}$ ), however, the regression results show a negative relationship. The opportunities created by the European Single Market to easily extend sales territory thus seem to increase revenue efficiency. In addition, for life insurers, these possibilities improve the ability to choose best-practice technology and the cost-minimal input combinations. $\mathrm{P} / \mathrm{c}$ insurers seem to react differently to these opportunities, which might be explained by the "liability of foreignness"

models are less than 5 . The correlations of international diversification with other variables are even smaller (see Online-Appendix C).

23 A second measure for specialization (companies are defined to be specialized if two-thirds of their total premiums were earned in one line of business; otherwise not) was applied and obtained the same results for this determinant. 
argument (see, e.g., Zaheer, 1995), which notes that complexity and cost of coordination, especially for large foreign operations, as well as cultural differences between the home and the foreign markets, are viewed as major barriers to successful international diversification. In Section 4.4.3, we look at interaction effects, by which we show a positive effect on p/c insurers' TE and CE that depends on size and the level of specialization (the negative effect between international diversification and efficiency occurs only for highly specialized $\mathrm{p} / \mathrm{c}$ insurers, and in particular for those that are small and highly specialized). The regression results thus partly support hypothesis H2. This result is in line with Altuntas and Gößmann (2012), who observe a positive relation between return on assets and international diversification for German insurers. The findings imply that internationalization strategies and increasing the number of international operations (e.g., via mergers and acquisitions) is beneficial from an efficiency point of view for life insurers and also for $\mathrm{p} / \mathrm{c}$ insurers as long as the latter are not highly specialized, and particularly as long as they are not small and highly specialized simultaneously. ${ }^{24}$

Size and Economies of Scale: In Table 5, we find an increase in TE, CE, and RE with increasing size for life and $\mathrm{p} / \mathrm{c}$ insurance. The regression result thus confirms a positive trend for both subsectors and all efficiency measures, supporting hypothesis H3(a). There are also significant positive results for TE and $\mathrm{CE}$ in reinsurance, but for RE we observe a negative effect. This result is different from the life and $\mathrm{p} / \mathrm{c}$ market and might be connected to an interaction effect present between size and specialization (see Section 4.4.3). For reinsurers' RE, the findings in Rai (1996) are confirmed. However, our results for life and p/c insurance, and for TE and CE in reinsurance are against Rai (1996), although in accordance with much of the efficiency literature (e.g., Cummins and Zi, 1998; Luhnen, 2009; and Eling and Luhnen, $2010 b){ }^{25}$

In Table 6, we analyze economies of scale. We define three equal-sized size groups and look at the distribution of return to scales for each group. For all three sectors, firms from the "Small" category mostly operate under IRS and CRS, while those from the "Large" group mostly operate under DRS. The pattern for medium-sized insurers is not as clear-cut. The results in Table 6 are consistent with analyses in other countries (see, e.g., Yuengert, 1993 and Cummins and Zi, 1998 for U.S. life insurance; Hardwick, 1997 for U.K. life insurance; Luhnen, 2009 for German p/l insurance) and the literature on whole insurance markets (e.g., Cummins and Rubio-Misas, 2006 for Spain), and confirm hypothesis H3(b). Our results fur-

24 Using the approach of Grace et al. (2014) we also computed the potential monetary advantages; that is, cost savings and revenue enhancements (see Online-Appendix D).

25 An additional test using quadratic terms in the regression is provided in Section 4.4.2 and shows a u-shaped relationship. 
ther indicate that mergers among small and medium-sized insurers can be justified on efficiency grounds, but that mergers among larger insurers cannot. ${ }^{26}$

Table 6 Economies of Scale

\begin{tabular}{|c|c|c|c|}
\hline $\begin{array}{l}\text { Size } \\
\text { class }\end{array}$ & $\begin{array}{l}\text { Increasing return } \\
\text { to scale (IRS) in \% }\end{array}$ & $\begin{array}{c}\text { Constant return } \\
\text { to scale (CRS) in \% }\end{array}$ & $\begin{array}{l}\text { Decreasing return } \\
\text { to scale (DRS) in \% }\end{array}$ \\
\hline \multicolumn{4}{|l|}{ Panel A: life insurance } \\
\hline Small $(\mathrm{TA}<931 \mathrm{M})$ & 52 & 42 & 6 \\
\hline Medium & 15 & 47 & 38 \\
\hline Large $(\mathrm{TA}>6,544 \mathrm{M})$ & 2 & 32 & 66 \\
\hline \multicolumn{4}{|l|}{ Panel B: $p / c$ insurance } \\
\hline Small $(\mathrm{TA}<41 \mathrm{M})$ & 68 & 29 & 3 \\
\hline Medium & 49 & 20 & 31 \\
\hline Large $(\mathrm{TA}>280 \mathrm{M})$ & 7 & 21 & 72 \\
\hline \multicolumn{4}{|l|}{ Panel C: reinsurance } \\
\hline Small $(\mathrm{TA}<28 \mathrm{M})$ & 64 & 33 & 3 \\
\hline Medium & 43 & 40 & 17 \\
\hline Large $(\mathrm{TA}>192 \mathrm{M})$ & 5 & 27 & 68 \\
\hline
\end{tabular}

Specialization (Economies of Scope): The analysis of firm specialization shows significant negative impact of specialization on TE in all sectors (see Table 5). Thus, a high level of specialization hinders the ability of firms to choose the best-practice technology. Regarding RE of life and $\mathrm{CE}$ of $\mathrm{p} / \mathrm{c}$ insurance we also observe this negative relationship. Our results thus indicate support of the conglomeration hypothesis, which has found a great deal of support using U.S. data (see, e.g., Meador et al., 2000). The hypothesized positive effect between the degree of specialization and efficiency can be confirmed only for RE in $\mathrm{p} / \mathrm{c}$ and reinsurance, thus, making specialized $\mathrm{p} / \mathrm{c}$ and reinsurers more effective in choosing the revenuemaximizing output combinations. The strategic focus hypothesis $(\mathrm{H} 4)$ and results from Rai (1996) thus can be confirmed only for RE in the $\mathrm{p} / \mathrm{c}$ and the reinsurance market. As indicated above, the analysis of interaction effects (Section 4.4.3) is very useful for explaining the coexistence of large, diversified and small, specialized firms.

Organizational Form: In the life insurance sector, mutual insurers are more efficient than stocks in TE, CE, and RE. This effect is confirmed in p/c insurance for the TE and CE measure, whereas the RE measure is not significant. All these findings lead to a rejection of the expense preference hypothesis (see Mester, 1991) and thus hypothesis H5. This finding is in

26 We analyze the economies of scale in more detail in Online-Appendix E. We find that the majority of life insurers with assets up to CHF 3.6 billion operate under IRS and CRS, whereas for $\mathrm{p} / \mathrm{c}$ and reinsurance, the critical triggers for this are about CHF 100 million (reinsurance) to CHF 191 million (p/c). The merger threshold for life insurers is higher than the threshold in Cummins and Zi (1998), but the result for $\mathrm{p} / \mathrm{c}$ is close to the U.S. value documented in Cummins and Xie (2013). Nevertheless, the potential efficiency benefits must outweigh the merger costs. Thus, due to the already high level of scale efficiency in the Swiss market, the efficiency gains from a merger might be limited for small insurers. It must also be noted that even among the largest insurers we find some that operate under IRS and CRS, indicating that there may be important managerial lessons to be learned from scale-efficient insurers (see Cummins and Xie, 2013). 
line with Luhnen (2009) for the German p/l market as well as with Biener and Eling (2012) for the European and U.S. markets.

Leverage: The results are unambiguous on the relation between leverage and efficiency: increasing leverage has a negative effect on TE, CE, and RE across the entire Swiss insurance market. We confirm hypothesis H6 for all efficiency measures and all subsectors.

Premium Growth: The regression results for premium growth (Table 5) do not reveal a clear pattern over all subsectors. We find a positive relationship between premium growth and all efficiency measures in reinsurance; for life insurance we observe a positive relationship for $\mathrm{RE}$ and for $\mathrm{p} / \mathrm{c}$ insurance for TE. This is not in line with hypothesis H7. The only case in which we can support the hypothesized negative link is RE in the p/c insurance industry. Except for this one confirmation of $\mathrm{H} 7$, all other coefficients in Table 5 are zero or in a direction opposite to that expected; consequently, we cannot support hypothesis $\mathrm{H} 7$ with our sample.

Company Age: Company age is the time span between the founding year and 2013. There is a significant positive relation between age and efficiency in $\mathrm{p} / \mathrm{c}$ insurance and for reinsurers' RE. The findings are not in line with hypothesis H8. However, the hypothesized negative effect of company age on efficiency can be confirmed in reinsurance for TE and CE.

\subsection{Further Tests}

\subsubsection{Analysis of Subperiods}

Table 7 compares the regression results from Table 5 within different subperiods (before the first crisis, i.e., 1997-2001, between the two crises, i.e., 2002-2007, and for 2008-2013). Although the idea of cross-checking and comparing efficiency estimates across different time periods is very straightforward, it is not usually done in efficiency studies, typically due to data limitations. Our results underline the fact that these cross-checks are important, since results can very much depend on the time period considered. 
Table 7 Truncated Regression Results per Subperiod

\begin{tabular}{|c|c|c|c|c|c|c|c|c|c|c|c|c|c|c|c|}
\hline \multirow[b]{2}{*}{ Variable } & \multicolumn{3}{|c|}{ 1997-2013 } & \multicolumn{3}{|c|}{ 1997-2001 } & \multicolumn{3}{|c|}{ 2002-2007 } & \multicolumn{3}{|l|}{ 2008-2013 } & \multicolumn{3}{|c|}{ Significance per variable and sector } \\
\hline & TE & CE & $\mathbf{R E}$ & TE & CE & $\mathbf{R E}$ & TE & CE & $\mathbf{R E}$ & TE & CE & $\mathbf{R E}$ & + & $\mathbf{0}$ & - \\
\hline \multicolumn{16}{|c|}{ Panel A: life insurance } \\
\hline Int'l div. & $-0.86^{* * * *}$ & $-1.59 * * *$ & $-1.53 * * *$ & $-1.56^{* *}$ & $-0.39 * * *$ & $-0.33^{* *}$ & $-0.47 * * *$ & $-0.95^{* * *}$ & $-1.69^{* * *}$ & -1.60 & 5.49 & -0.86 & 0 & 3 & 9 \\
\hline Size & $-0.08 * * *$ & $-0.13 * * *$ & $-0.07 * * *$ & $-0.35 * * *$ & $-0.17 * * *$ & $-0.17^{* * *}$ & $-0.07 * * *$ & $-0.09 * * *$ & $-0.07 * * *$ & $-0.07 *$ & $-0.59 * * *$ & -0.04 & 0 & 1 & 11 \\
\hline Spec. & $0.18^{*}$ & 0.00 & $0.21^{* *}$ & $-1.29 * *$ & $-0.95 * * *$ & -0.12 & $0.37 * * *$ & $0.33^{* * *}$ & $0.36^{* * *}$ & 0.19 & -0.10 & $0.46^{*}$ & 6 & 4 & 2 \\
\hline Org. form & $0.69^{* * *}$ & $1.23^{* * *}$ & $1.11^{* * *}$ & $1.48^{* * *}$ & $2.33^{* * *}$ & $1.26^{* * *}$ & $0.59^{* * *}$ & $0.81^{* * *}$ & $0.90^{* * *}$ & $0.95^{* * *}$ & $4.92^{* * *}$ & $1.51^{* * *}$ & 12 & 0 & 0 \\
\hline Leverage & $1.32 * * *$ & $1.88^{* * *}$ & $1.19 * * *$ & $7.38^{* * *}$ & $2.67 * * *$ & $3.08^{* * *}$ & $1.08^{* * *}$ & $1.36^{* * *}$ & $1.03^{* *}$ & $0.94 *$ & $6.80^{* *}$ & 0.30 & 11 & 1 & 0 \\
\hline Premium growth & -0.07 & -0.13 & $-0.17 * * *$ & -0.03 & -0.14 & $-0.19^{* * *}$ & -0.03 & -0.11 & $-0.17^{* *}$ & -0.09 & 0.14 & -0.11 & 0 & 9 & 3 \\
\hline Age & 0.05 & 0.05 & 0.03 & -0.05 & -0.02 & $0.10^{* * *}$ & $0.11^{* *}$ & $0.12^{* * *}$ & 0.05 & 0.11 & 0.26 & -0.08 & 3 & 9 & 0 \\
\hline $\begin{array}{l}\text { Sigma } \\
\end{array}$ & $0.10 * * *$ & $0.14^{* * *}$ & $0.12 * * *$ & $0.11 * * *$ & $0.11 * * *$ & $0.08^{* * *}$ & $0.08^{* * *}$ & $0.10^{* * *}$ & $0.11 * * *$ & $0.12 * * *$ & $0.33^{* * * *}$ & $0.16^{* * *}$ & $\overline{12}$ & 0 & 0 \\
\hline \# of observations & 359 & 359 & 359 & 111 & 111 & 111 & 129 & 129 & 129 & 119 & 119 & 119 & & & \\
\hline \multicolumn{16}{|c|}{ Panel B: $p / c$ insurance } \\
\hline Int'l div. & $9.70^{* * *}$ & $11.92 * *$ & $-7.82 * * *$ & $12.70^{* * *}$ & $8.54 * * *$ & -0.20 & $-1.76^{* * *}$ & -0.47 & $-38.05^{* * *}$ & -13.11 & -4.00 & 0.60 & 4 & 5 & 3 \\
\hline Size & $-0.73 * * *$ & $-1.44 * * *$ & $-0.52 * * *$ & $-0.91 * *$ & $-0.65 * *$ & 0.02 & 0.01 & -0.06 & 0.18 & $-2.51 * *$ & -1.42 & -0.14 & 0 & 6 & 6 \\
\hline Spec. & $2.88^{* * *}$ & $8.41^{* * *}$ & $-3.65^{* * *}$ & 1.47 & $3.69^{* *}$ & -0.04 & -0.12 & $0.76^{* * *}$ & $-5.75^{* *}$ & $11.52^{* * *}$ & $20.10^{* * *}$ & $0.60^{*}$ & 7 & 3 & 2 \\
\hline Org. form & $6.44 * * *$ & $16.34^{* * * *}$ & 0.11 & $15.19^{* * *}$ & $10.69^{* * *}$ & 0.08 & $1.25^{* * *}$ & $1.39^{* * *}$ & 1.39 & 3.40 & 5.04 & 0.27 & 6 & 6 & 0 \\
\hline Leverage & $7.90^{* * *}$ & $6.02 *$ & $8.53 * * *$ & 5.75 & 2.35 & $0.66^{* * *}$ & 0.59 & 0.18 & 3.05 & $31.67 * * *$ & 14.76 & $5.15^{* * *}$ & 5 & 7 & 0 \\
\hline Premium growth & $-3.85^{* * *}$ & -2.33 & $1.72^{*}$ & 1.56 & $3.08^{*}$ & 0.14 & 0.33 & 0.37 & 2.68 & $-18.63^{* * *}$ & $-21.26^{* * *}$ & -0.06 & 2 & 7 & 3 \\
\hline Age & $-3.75^{* * *}$ & $-8.47 * * *$ & $-2.68 * * *$ & $-4.86^{* * *}$ & $-3.77 * * *$ & $-0.08^{*}$ & $-0.53 * * *$ & $-0.32 * *$ & $-5.49 * * *$ & $-3.60 *$ & $-12.62 * * *$ & $-0.62 * *$ & 0 & 0 & 12 \\
\hline Sigma & $1.27^{* * *}$ & $2.45^{* * *}$ & $1.10^{* * *}$ & $1.31^{* * *}$ & $1.49 * * *$ & $0.19 * * *$ & $0.43 * * *$ & $0.57 * * *$ & $1.80^{* * *}$ & $1.90^{* * *}$ & $3.00^{* * *}$ & $0.57^{* * *}$ & 12 & 0 & 0 \\
\hline \# of observations & 882 & 882 & 882 & 229 & 229 & 229 & 333 & 333 & 333 & 320 & 320 & 320 & & & \\
\hline \multicolumn{16}{|c|}{ Panel C: reinsurance } \\
\hline Int'l div. & -- & - & -- & -- & -- & -- & -- & -- & -- & -- & -- & -- & -- & -- & -- \\
\hline Size & $-1.96 * * *$ & $-6.83^{* * *}$ & $0.07^{* * *}$ & -2.08 & 1.08 & $0.05^{* * *}$ & $-1.20 * * *$ & $-3.45^{* * *}$ & $0.01 *$ & $-6.13 * * *$ & $-10.52^{* * *}$ & $0.05^{* * *}$ & 4 & 2 & 6 \\
\hline Spec. & 2.11 & -2.58 & $-0.92^{* * *}$ & -13.84 & $-51.88^{* *}$ & $-0.76^{* * *}$ & -0.14 & 3.21 & $-0.49^{* * *}$ & -1.54 & -5.46 & $0.10^{* * *}$ & 1 & 7 & 4 \\
\hline Org. form & -- & -- & -- & -- & -- & -- & -- & -- & -- & -- & -- & -- & -- & -- & -- \\
\hline Leverage & $20.78^{* * * *}$ & $90.46^{* * * *}$ & $0.69^{* * *}$ & $20.17 *$ & -4.22 & $0.84 * * *$ & $16.96^{* * *}$ & $49.64 * * *$ & $0.88^{* * *}$ & -18.52 & $131.21^{* * *}$ & $0.09 * *$ & 10 & 2 & 0 \\
\hline Premium growth & $-4.59 * * *$ & $-3.54 * *$ & $-0.37 * * *$ & -0.65 & 3.40 & -0.04 & $-5.27 * * *$ & $-9.38 * * *$ & $-0.46 * * *$ & 4.59 & -0.54 & -0.01 & 0 & 6 & 6 \\
\hline Age & $3.09 * *$ & $5.50^{* * *}$ & $-0.27^{* * *}$ & -3.68 & $-21.10^{*}$ & $-0.19 * * *$ & $2.16^{* * *}$ & 3.44 & 0.03 & $10.11^{*}$ & $14.79 * * *$ & $-0.09 * * *$ & 5 & 3 & 4 \\
\hline Sigma & $2.06^{* * *}$ & $3.67 * * *$ & $0.13^{* * *}$ & $1.87^{* * *}$ & $3.63^{* * *}$ & $0.06^{* * *}$ & $1.24 * * *$ & $2.79^{* * *}$ & $0.09^{* * *}$ & $3.53^{* * *}$ & $4.51^{* * *}$ & $0.06^{* * *}$ & 12 & 0 & 0 \\
\hline \# of observations & 633 & 633 & 633 & 98 & 98 & 98 & 234 & 234 & 234 & 301 & 301 & 301 & & & \\
\hline
\end{tabular}

Note: $* * *, * *$, and $*$ denote the statistical significance level at the $1 \%, 5 \%$, and $10 \%$ level, respectively. $\mathrm{TE}=$ technical efficiency, $\mathrm{CE}=$ cost efficiency, and $\mathrm{RE}=$ revenue efficiency. In all models, year dummies are included.

The only determinants that show consistent results across all time periods and all subsectors are organizational form and leverage. In Switzerland it thus seems clear that mutuals exhibit superior performance as compared with stocks in terms of efficiency and that high leverage is detrimental to efficiency. For some variables, results are also consistent across all time periods, but, as already shown in Table 5, not across different subsectors: for size, the link is clearly positive for life and p/c, but ambiguous for reinsurance. For age, the link is positive for $\mathrm{p} / \mathrm{c}$, negative for life, and positive as well as negative for reinsurance. While premium growth is positive for life and reinsurance, no clear pattern is observable for $\mathrm{p} / \mathrm{c}$. Similar is true for the international diversification effect. Finally, specialization does not show consistent effects across subperiods at all.

\subsubsection{Analysis of Nonlinear Relationships}

For several variables (international diversification, size, specialization, leverage, premium growth, and company age), there are arguments for both positive and negative links with efficiency. Economic theory might thus suggest nonlinear links between these variables and efficiency. To test for such nonlinear relationships, we include the quadratic term for size, spe- 
cialization, leverage, premium growth, and company age. ${ }^{27}$ Adding the square term is inappropriate for the variable internationalization due to high correlation. We thus split our sample into four categories and implement the analysis categorically. ${ }^{28}$

Table 8 Truncated Regression Results for Nonlinear Relationships

\begin{tabular}{|c|c|c|c|c|c|c|c|c|c|}
\hline \multirow[b]{2}{*}{ Variable } & \multicolumn{3}{|c|}{ life insurance } & \multicolumn{3}{|c|}{ p/c insurance } & \multicolumn{3}{|c|}{ reinsurance } \\
\hline & $T E$ & $C E$ & $R E$ & $T E$ & $C E$ & $R E$ & $T E$ & $C E$ & $R E$ \\
\hline Int'l div. G2 & $0.26 * * *$ & 0.12 & 0.09 & -0.76 & 0.36 & -0.10 & -- & -- & -- \\
\hline Int'1 div. G3 & 0.00 & 0.12 & 0.14 & $1.50 * *$ & $0.96 *$ & -0.24 & -- & -- & -- \\
\hline Int'l div. G4 & -0.10 & -0.08 & -0.02 & $2.34 * * *$ & $2.44 * * *$ & $-0.79 * * *$ & -- & -- & -- \\
\hline Size & $-0.03 *$ & $-0.06 * * *$ & $-0.05 * *$ & $-0.35 * * *$ & $-0.59 * * *$ & $0.25 * * *$ & $1.82 * * *$ & $2.42 * * *$ & $0.31 * * *$ \\
\hline $\mathrm{Size}^{\wedge} 2$ & -0.01 & $-0.02 *$ & $-0.06 * * *$ & $-0.15 * * *$ & $-0.14 * * *$ & $-0.23 * * *$ & $-0.24 * * *$ & $-0.69 * * *$ & $-0.05 * * *$ \\
\hline Specialization & $0.32 * *$ & 0.04 & $0.35 * * *$ & -0.02 & -0.53 & -0.04 & $11.38 * * *$ & $13.50 * * *$ & $0.23 * *$ \\
\hline Specialization $^{\wedge} 2$ & -0.36 & 0.23 & -0.67 & $6.97 * *$ & 2.58 & $2.07 * *$ & $-50.66 * * *$ & $-92.83 * * *$ & -0.40 \\
\hline Organizational form & $0.63 * * *$ & $0.79 * * *$ & $1.20 * * *$ & $-1.76 * * *$ & $-0.96 * *$ & -0.15 & -- & -- & -- \\
\hline Leverage & -0.28 & $-2.17 * *$ & $-2.59 * * *$ & $-1.63 * *$ & $-1.98 * *$ & $-1.64 * * *$ & $8.29 * * *$ & $27.94 * * *$ & $0.13 * * *$ \\
\hline Leverage $^{\wedge} 2$ & $-6.13 *$ & $-11.41 * * *$ & $-13.93 * * *$ & $-15.70 * * *$ & $-12.96 * * *$ & $-15.15 * * *$ & $-13.29 * *$ & $11.01 * *$ & -0.26 \\
\hline Premium growth & -0.15 & $-0.23 * *$ & $-0.22 * * *$ & $-1.00 * *$ & $-0.54 *$ & 0.03 & -0.25 & 0.69 & $-0.06 * * *$ \\
\hline Premium growth^2 & $-0.48 * * *$ & $-0.58 * * *$ & $-0.23 * *$ & 0.65 & $0.73 * *$ & 0.07 & -0.06 & -0.51 & 0.01 \\
\hline Age & -0.10 & -0.05 & -0.02 & $-2.11 * * *$ & $-1.70 * * *$ & $-0.16^{*}$ & $5.41 * * *$ & $11.65 * * *$ & $0.08 * *$ \\
\hline $\mathrm{Age}^{\wedge} 2$ & $-0.21 * * *$ & $-0.13 * * *$ & $-0.08 * * *$ & $-0.44 * *$ & -0.14 & $0.12 *$ & $-4.99 * * *$ & $-10.29 * * *$ & $-0.09 * * *$ \\
\hline Sigma & $0.10 * * *$ & $0.11 * * *$ & $0.11 * * *$ & $0.72 * * *$ & $0.82 * * *$ & $0.45 * * *$ & $1.20 * * *$ & $2.45 * * *$ & $0.07 * * *$ \\
\hline Number of observations & 359 & 359 & 359 & 882 & 882 & 882 & 633 & 633 & 633 \\
\hline
\end{tabular}

Note: $* * *, * *$, and $*$ denote the statistical significance level at the $1 \%, 5 \%$, and $10 \%$ level, respectively. TE $=$ technical efficiency, $\mathrm{CE}=$ cost efficiency, and $\mathrm{RE}=$ revenue efficiency. In all models, year dummies are included. To avoid multicollinearity we mean-centered variables size, specialization, leverage, premium growth, and age.

The results (Table 8) show no clear nonlinear effect for international diversification. Beside the linear effect of size on efficiency (Table 5), there are convex relationships for size and efficiency in almost all models: small and large firms are more efficient than medium-sized firms. This result, in combination with the findings from Section 4.4.3, indicates that in Switzerland it is better to be either a small specialist or a large diversified company. For specialization, we observe a concave relation for $\mathrm{p} / \mathrm{c}$ insurers, indicating that there is an optimal level of specialization in the $\mathrm{p} / \mathrm{c}$ insurance industry. In reinsurance, this effect seems to be convex, while in life insurance there is no nonlinear effect. For leverage, we also find a convex relation in life and $\mathrm{p} / \mathrm{c}$ insurance, whereas reinsurers exhibit no clear pattern of nonlinear effect relations (i.e., TE shows a convex, $\mathrm{CE}$ a concave, and $\mathrm{RE}$ no other than the negative trend observed in Table 5). When it comes to a nonlinear relationship between premium growth and efficiency, the results are ambiguous: life insurers show a convex relation, while p/c insurers' $\mathrm{CE}$ shows a concave relation, and reinsurance shows no relation at all. The results for age are unambiguous (with one exception: p/c insurers' RE), showing a convex relation. Although some results seem to be equivocal, the analysis clearly illustrates that testing linear relations alone is generally not sufficient.

27 We thus test whether there is a u-shape or optimal size, degree of specialization, degree of leverage, premium growth, or age. For size, this test has already been done in the literature, see, e.g., Worthington and Hurley (2002). However, to our knowledge, the other variables have not yet been tested.

28 One group consists of firms with no international diversification (Group 1) and the three other equal-sized groups have least (Group 2), medium (Group 3), and most (Group 4) amounts of the int'l div. measure. 


\subsubsection{Analysis of Interactions}

Some research suggests that an analysis of interactions may identify efficient structures (see, e.g., Berger et al., 2000). In Table 9 we analyze the different dimensions of diversification (increase of size, product diversification, and geographical diversification), that is, we interact international diversification, size, and specialization to discover whether the coexistence of conglomerates and specialized insurers is justified from an efficiency point of view.

Table 9 Truncated Regression Results for Interactions

\begin{tabular}{|c|c|c|c|c|c|c|c|c|c|}
\hline \multirow[b]{2}{*}{ Variable } & \multicolumn{3}{|c|}{ life insurance } & \multicolumn{3}{|c|}{ p/c insurance } & \multicolumn{3}{|c|}{ reinsurance } \\
\hline & $T E$ & $C E$ & $R E$ & $T E$ & $C E$ & $R E$ & $T E$ & $C E$ & $R E$ \\
\hline Organizational form & $0.32 * * *$ & $0.38 * * *$ & $0.63 * * *$ & $1.40^{*}$ & $4.48 * * *$ & -0.25 & -- & -- & -- \\
\hline Leverage & $0.41 * *$ & $0.44 * * *$ & $0.34 * *$ & $8.28 * * *$ & $8.08 * * *$ & $1.17 * *$ & -0.74 & $31.06 * * *$ & $0.61 * * *$ \\
\hline Premium growth & -0.05 & $-0.06^{*}$ & $-0.15 * * *$ & $-2.95 * *$ & -1.89 & $0.44 *$ & $-5.30 * * *$ & $-2.62 *$ & $-0.30 * * *$ \\
\hline Age & 0.00 & 0.00 & -0.01 & $-4.49 * * *$ & $-6.61 * * *$ & $-0.90 * * *$ & $-1.38 * *$ & $-10.48 * * *$ & $-0.11 * * *$ \\
\hline Int'l diversification & $-0.61 * * *$ & $-1.00 * * *$ & $-1.74 * * *$ & 1.02 & 5.85 & $-3.03 * * *$ & -- & -- & -- \\
\hline Size & $-0.03 * *$ & $-0.04 * * *$ & $-0.03 * * *$ & $-1.15 * * *$ & $-2.82 * * *$ & 0.01 & $3.20 * * *$ & $3.98 * * *$ & $0.29 * * *$ \\
\hline Specialization & 0.07 & -0.10 & 0.04 & -2.55 & -3.33 & $-1.94 * * *$ & $9.85 * * *$ & $13.20 * *$ & $-0.94 * * *$ \\
\hline Int'l div. $x$ Size & -0.05 & 0.04 & $-0.33^{*}$ & -0.14 & 0.11 & $-0.76^{*}$ & -- & -- & -- \\
\hline Int'l div. $\mathrm{x}$ Specialization & -1.67 & $-3.33 * *$ & $-6.91 * * *$ & $20.88 *$ & 8.89 & $-11.21 * * *$ & -- & -- & -- \\
\hline Size x Specialization & -0.02 & -0.03 & 0.00 & $2.37 * * *$ & $6.06 * * *$ & $1.58 * * *$ & $7.89 * * *$ & $15.65 * * *$ & $0.63 * * *$ \\
\hline Int'l div. x Size x Spec. & -0.55 & -1.21 & $-2.98 * * *$ & $-5.75^{*}$ & $-4.72 *$ & $-0.45^{*}$ & -- & -- & -- \\
\hline Sigma & $0.08 * * *$ & $0.09^{* * *}$ & $0.10 * * *$ & $1.17 * * *$ & $1.81 * * *$ & $0.60 * * *$ & $2.10 * * *$ & $4.21 * * *$ & $0.11 * * *$ \\
\hline Number of observations & 359 & 359 & 359 & 882 & 882 & 882 & 633 & 633 & 633 \\
\hline
\end{tabular}

Note: $* * *, * *$, and $*$ denote the statistical significance level at the $1 \%, 5 \%$, and $10 \%$ level, respectively. TE $=$ technical efficiency, $\mathrm{CE}=$ cost efficiency, and $\mathrm{RE}=$ revenue efficiency. In all models, year dummies are included. To reduce multicollinearity and improve interpretability we mean-centered variables Int'l diversification, Size, and Specialization.

For life insurance, there is only a significant interaction between the three variables in RE. A plot of changes in the predicted efficiency scores for high and low levels of international diversification (see Figure 1(a)) shows that, in general, there is a positive relation between international diversification and RE, but for large diversified firms this trend becomes negative. For $\mathrm{p} / \mathrm{c}$ insurance, the interaction is significant for all measures. Plots for changes in predicted efficiency (Figure 1(b) as an example) reveal that the negative effect of international diversification on TE and CE (Table 5) is caused by highly specialized firms; particularly, when they are small and highly specialized. This means that being specialized (and being small and specialized) is sufficient in itself for efficiency. For these firms, international diversification may be too complex, and thus detrimental to efficiency. According to Berger et al. (2000), the conglomeration hypothesis dominates for some types of financial services (i.e., larger insurers with emphasis on personal lines and vertically integrated distribution systems) and the strategic focus hypothesis dominates for other types (i.e., smaller insurers with emphasis on commercial lines and nonintegrated distribution systems). Thus, extending the Berger et al. (2000) hypothesis with a geographical diversification component could be worthwhile. For reinsurance, we just analyze the interaction of specialization and size. The results and plots of changes in predicted efficiency scores (Figure 1(c) as an example) underline the argument found in 
Berger et al. (2000) that specialization is especially advantageous for small firms and diversification for large firms.

Figure 1 Predicted Efficiency Change for Increasing the Degree of Int'l Diversification ((a) and (b)) and Specialization (c)
(a) RE in life insurance
(b) TE in $\mathrm{p} / \mathrm{c}$ insurance
(c) TE in reinsurance
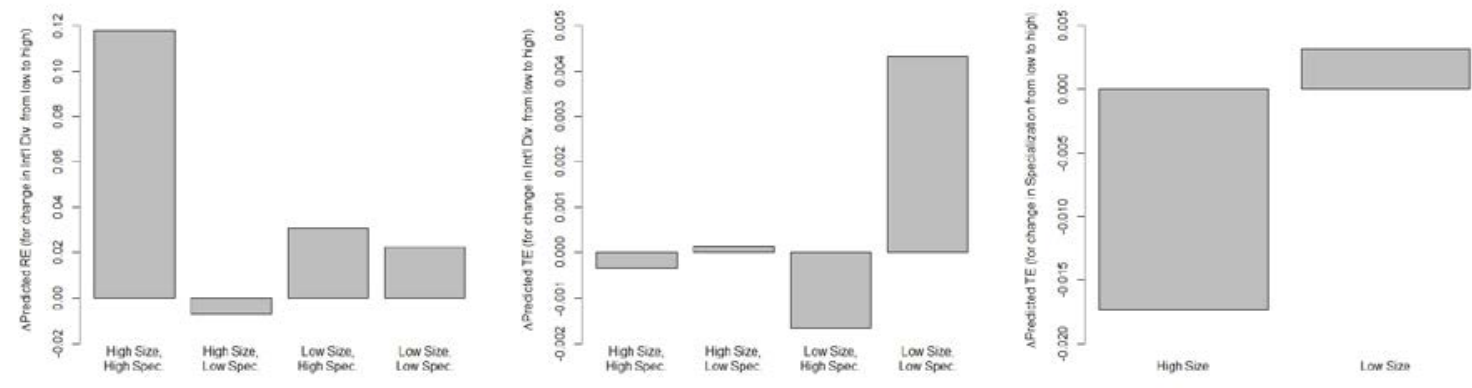

Note: Figures 1(a) and 1(b) present the change in the predicted efficiency value when a company increases its level of international diversification from low to high, shown for exemplary firms that are defined by low and high levels in size and specialization (high/low are one standard deviation above/below the mean of each variable). Figure 1(c) presents the change in the predicted efficiency value if a company increases its level of specialization from low to high, shown for exemplary firms that are defined by a low and high level of size.

\section{Conclusions}

We study the productivity and efficiency of Swiss firms active in the life, $\mathrm{p} / \mathrm{c}$, and reinsurance market from 1997-2013 using frontier efficiency methodologies. The Swiss insurance market has undergone major changes in the last 20 years, including deregulation, increased competition, changing capital market conditions, and changing supervisory and legal frameworks. These major changes are reflected in substantial productivity and efficiency changes.

A summary of all results and a comparison with the extant literature is provided in Table 10. In the $\mathrm{p} / \mathrm{c}$ and reinsurance markets, yearly average productivity increased slightly over the sample period due to similar degrees of improvement in both the technology frontier and efficiency. In contrast, we find a decline of best practice technology for life insurance firms giving rise to a decline in productivity. And yet, even though the best practice firms became less productive, the average insurer was not able to catch up to them. We interpret these findings as illustrating the difficulties experienced by the entire life insurance sector in adapting to the increasingly challenging business environment (e.g., low interest rates, increased competition from other financial services providers). Our results suggest that the internationalization of the Swiss insurance industry as well as increasing the size of operation have a positive impact on insurer efficiency. Furthermore, interaction effects are important to consider since they reveal that being either a small specialist or a large diversified company is optimal from an efficiency point of view. This finding is in line with the general literature on strategic man- 
agement (e.g., Porter, 1980) and efficiency (e.g., Berger et al., 2000). Moreover, we find that stock firms are not more efficient than mutual firms, a rejection of the expense preference hypothesis (Mester, 1991). High debt ratios are detrimental to insurer efficiency.

Table 10 Summary of Results and Comparison with the Extant Literature

\begin{tabular}{|c|c|c|c|c|}
\hline & & Hypothesis & Our results & Comparison with extant literature \\
\hline H1 & $\begin{array}{l}\text { Development of } \\
\text { productivity and } \\
\text { efficiency over } \\
\text { time }\end{array}$ & $\begin{array}{l}\text { Productivity and efficiency } \\
\text { in the Swiss insurance } \\
\text { market increased from 1997- } \\
2013 .\end{array}$ & $\begin{array}{l}\text { Hypothesis confirmed for } \mathrm{p} / \mathrm{c} \text { and } \\
\text { reinsurance due to best practice } \\
\text { technology progress and im- } \\
\text { provements in technical efficien- } \\
\text { cy. Hypothesis rejected for life } \\
\text { insurance. }\end{array}$ & $\begin{array}{l}\text { Donni and Fecher (1997) find a similar degree of } \\
\text { change in the Swiss market for 1983-1991. } \\
\text { Luhnen (2009) obtains similar, and Bertoni and } \\
\text { Croce (2011) higher overall, results for German } \\
\text { p/l insurance for } 1995-2006 \text { and for five Europe- } \\
\text { an life insurance markets in the period 1997- } \\
2004 \text {. }\end{array}$ \\
\hline H2 & $\begin{array}{l}\text { International } \\
\text { diversification }\end{array}$ & $\begin{array}{l}\text { Positive relationship between } \\
\text { the level of international } \\
\text { diversification and efficien- } \\
\text { cy. }\end{array}$ & $\begin{array}{l}\text { Hypothesis confirmed for life; } \\
\text { weaker evidence for } \mathrm{p} / \mathrm{c} \text {, effect } \\
\text { depends on interactions with size } \\
\text { and specialization (positive effect } \\
\text { especially for large firms). }\end{array}$ & Not yet analyzed. $^{29}$ \\
\hline H3 & $\begin{array}{l}\text { Size and econo- } \\
\text { mies of scale }\end{array}$ & $\begin{array}{l}\text { (a) Positive relationship } \\
\text { between firm size and effi- } \\
\text { ciency; (b) Small and medi- } \\
\text { um-sized insurers operate } \\
\text { under IRS, but large firms } \\
\text { mostly operate under DRS or } \\
\text { CRS. }\end{array}$ & $\begin{array}{l}\text { Hypothesis (a) is confirmed for } \\
\text { all subsectors and efficiency } \\
\text { measures; rejection only for } \\
\text { reinsurers' RE. Hypothesis (b) is } \\
\text { confirmed; however, a great } \\
\text { many firms operate under CRS, a } \\
\text { number significantly higher than } \\
\text { in extant literature. }\end{array}$ & $\begin{array}{l}\text { (a) Cummins and Zi (1998); Luhnen (2009); } \\
\text { Eling and Luhnen (2010b). Just the reinsurance } \\
\text { sector partly supports the results for Switzerland } \\
\text { obtained in Rai (1996). (b) In line with literature: } \\
\text { Yuengert (1993) and Cummins and Zi (1998) for } \\
\text { U.S. life insurance, Hardwick (1997) for U.K. } \\
\text { life insurance, Luhnen (2009) for German p/l } \\
\text { insurance; also in line with literature on whole } \\
\text { insurance markets, e.g., Cummins and Rubio- } \\
\text { Misas (2006) for Spain. }\end{array}$ \\
\hline H4 & $\begin{array}{l}\text { Specialization } \\
\text { and economies of } \\
\text { scope }\end{array}$ & $\begin{array}{l}\text { Specialized insurers are more } \\
\text { efficient than diversified } \\
\text { insurers (strategic focus vs. } \\
\text { conglomeration). }\end{array}$ & $\begin{array}{l}\text { Hypothesis confirmed for RE in } \\
\mathrm{p} / \mathrm{c} \text { and reinsurance. Rejection for } \\
\mathrm{TE}, \mathrm{RE} \text { in life, and CE in } \mathrm{p} / \mathrm{c} \text {. } \\
\text { Thus, more evidence for con- } \\
\text { glomeration hypothesis. Effect } \\
\text { depends on interaction (small } \\
\text { firms should be specialized). }\end{array}$ & $\begin{array}{l}\text { Partly in line with Swiss results from Rai (1996), } \\
\text { although those do not refer to RE. However, } \\
\text { mostly results in line with those from other } \\
\text { countries (Meador et al., 2000; Cummins et al., } \\
\text { 2010). Results of Berger et al. (2000) confirmed. }\end{array}$ \\
\hline H5 & $\begin{array}{l}\text { Organizational } \\
\text { form }\end{array}$ & $\begin{array}{l}\text { Stock insurers are more } \\
\text { efficient than mutual insur- } \\
\text { ers. }\end{array}$ & $\begin{array}{l}\text { Hypothesis rejected for life and } \\
\mathrm{p} / \mathrm{c} \text { insurance. }\end{array}$ & $\begin{array}{l}\text { Results in line with Diacon et al. (2002) for } 15 \\
\text { European countries, Luhnen (2009) for the } \\
\text { German p/l market, and Biener and Eling (2012) } \\
\text { for life and non-life in } 21 \text { countries. }\end{array}$ \\
\hline H6 & Leverage & $\begin{array}{l}\text { Negative relationship be- } \\
\text { tween leverage and efficien- } \\
\text { cy. }\end{array}$ & $\begin{array}{l}\text { Confirmation for all subsectors } \\
\text { and all efficiency measures. }\end{array}$ & $\begin{array}{l}\text { In line with Luhnen's (2009) results for } \mathrm{p} / \mathrm{l} \\
\text { insurance in Germany. }\end{array}$ \\
\hline H7 & Premium growth & $\begin{array}{l}\text { Negative relationship be- } \\
\text { tween premium growth and } \\
\text { efficiency. }\end{array}$ & $\begin{array}{l}\text { Hypothesis mainly rejected } \\
\text { (exception: p/c insurer's RE). }\end{array}$ & $\begin{array}{l}\text { Results are not in line with Luhnen (2009), who } \\
\text { is the only one so far to analyze this hypothesis } \\
\text { and prove it for German p/l insurers for 1995- } \\
2006 \text {. }\end{array}$ \\
\hline
\end{tabular}

H8 Company age Negative relationship be- Hypothesis mainly rejected Hussels and Ward (2007) and Biener and Eling tween company age and (exception: reinsurer's TE and (2011) were able to prove the hypothesis. $\begin{array}{ll}\text { efficiency. } & \mathrm{CE}) . \mathrm{P} / \mathrm{c} \text { shows a positive link in }\end{array}$ all cases.

Note: $\mathrm{TFP}=$ total factor productivity, $\mathrm{TE}=$ technical efficiency, $\mathrm{CE}=$ cost efficiency, and $\mathrm{RE}=$ revenue efficiency.

Our findings are of interest for Swiss insurance company managers, regulators, and policymakers. Companies can benefit from internationalization strategies and from increasing the size of their company; alternatively they might specialize in niches. The economy of scale analysis provides managers and regulators with justification for M\&A approval—or disapproval. We find that M\&A between small and medium-sized firms (up to CHF 3.6 billion in life, up to CHF 191 million in p/c, and up to about CHF 100 million in reinsurance) is benefi- 
cial, but such is not the case for larger firms. The results of the scale economies analysis are not only important for managers, but also have important implications for regulatory policy dealing with consolidation and antitrust enforcement.

Our results also validate and help to better understand the determinants of productivity in the insurance sector. Organizational form has an impact on life and p/c insurers' success. High debt ratios are detrimental to insurer efficiency. These findings underline the importance and appropriate definition of risk-based capital standards by regulators. We also want to emphasize the importance of analyzing nonlinear relationships and interactions between different covariates in achieving a better explanation of the true effect underlying the data.

More research is needed on international diversification. An application to other markets and cross-country settings or an even more explicit analysis of the functional form of the relationship between international diversification intensity and efficiency (i.e., testing for u-, inverted $\mathrm{u}$-, or s-shaped relations with continuous variables) will be worthwhile. The data sample for such an analysis should contain estimates for international diversification for which nonlinear relationships can be tested (e.g., international diversification measures that are not highly correlated with their higher orders). Mediating this relation with connected covariates might be also convenient. Also interesting is the interrelation between risk-based capital standards and efficiency, which has not yet been explored. Finally, it might be interesting to more closely analyze market-specific determinants in a cross-country context, that is, for instance, to measure the impact of changes in market conditions on efficiency (e.g., interest rate, concentration, inflation, etc.). One promising new tool in this context, which, however, would require a cross-country analysis, is the incorporation of uncontrollable variables in the efficiency analysis (see, e.g., Huang and Eling, 2013). Such an analysis can be especially useful for better understanding the productivity and efficiency decline in the life insurance industry.

29 A few papers analyze the internationalization strategies of insurance companies, but use different measures. For example, Altuntas and Gößmann (2012) observe a positive relation between international diversification and home market performance for German insurers when considering return on assets. 


\section{References}

Afonso, A., St. Aubyn, M., 2006. Cross-country efficiency of secondary education provision: A semi-parametric analysis with non-discretionary inputs. Economic Modelling 23, 476-491.

Altuntas, M., Gößmann, G., 2012. The Relationship Between Home-Market Performance and Internationalization Decisions: Evidence from German Insurance Groups. Working Paper, University of Cologne.

Andrews, D. F., Pregibon, D., 1978. Finding the Outliers that Matter. Journal of the Royal Statistical Society, Series B 40(1), 85-93.

AXCO Insurance Information Services, 2013. Global Statistics Database.

Barros, C. P., Barroso, N., Borges, M. R., 2005. Evaluating the Efficiency and Productivity of Insurance Companies with a Malmquist Index: A Case Study for Portugal. Geneva Papers on Risk and Insurance-Issues and Practice 30(2), 244-267.

Barros, C. P., Nektarios, M., Assaf, A., 2010. Efficiency in the Greek Insurance Industry. European Journal of Operational Research 205(2), 431-436.

Berger, A. N., Cummins, J. D., Weiss, M. A., Zi, H., 2000. Conglomeration Versus Strategic Focus: Evidence from the Insurance Industry. Journal of Financial Intermediation 9(4), 323-362.

Berry-Stölzle, T. R., Hoyt, R. E., Wende, S., 2010. Successful Business Strategies for Insurers Entering and Growing in Emerging Markets. Geneva Papers on Risk and Insurance-Issues and Practice 35(1), 110-128.

Berry-Stölzle, T. R., Hoyt, R. E., Wende, S., 2013. Capital Market Development, Competition, Property Rights, and the Value of Insurer Product-Line Diversification: A Cross-Country Analysis. Journal of Risk and Insurance 80(2), 423-459.

Berry-Stölzle, T. R., Lai, G. L., Wende, S., 2009. The Effect of Regulation on Comparative Advantages of Different Organizational Forms: Evidence from the German Property-Liability Insurance Industry. Working Paper, University of Cologne.

Bertoni, F., Croce, A., 2011. The Productivity of European Life Insurers: Best-Practice Adaption vs. Innovation. Geneva Papers on Risk and Insurance-Issues and Practice 36(2), 165-185.

Biener, C., Eling, M., 2011. The Performance of Microinsurance Programs: A Data Envelopment Analysis. Journal of Risk and Insurance 78(1), 83-115.

Biener, C., Eling, M., 2012. Organization and Efficiency in the International Insurance Industry: A CrossFrontier Analysis. European Journal of Operational Research 221(2), 454-468.

Bikker, J. A., van Leuvensteijn, M., 2008. Competition and Efficiency in the Dutch Life Insurance Industry. Applied Economics 40(16), 2063-2084.

Buch, C. M., Koch, C. T., Koetter, M., 2014. Should I Stay or Should I Go? Bank Productivity and Internationalization Decisions. Journal of Banking and Finance 42(5), 266-282.

Capar, N., Kotabe, M., 2003. The Relationship Between International Diversification and Performance in Service Firms. Journal of International Business Studies 34(4), 345-355.

Caves, D. W., Christensen, L. R., Diewert, W. E., 1982. The Economic Theory of Index Numbers and the Measurement of Input, Output, and Productivity. Econometrica 50(6), 1393-1414.

Cummins, J. D., Nini, G. P., 2002. Optimal Capital Utilization by Financial Firms: Evidence from the PropertyLiability Insurance Industry. Journal of Financial Services Research 21(1-2), 15-53.

Cummins, J. D., Rubio-Misas, M., 2006. Deregulation, Consolidation, and Efficiency: Evidence from the Spanish Insurance Industry. Journal of Money, Credit, and Banking 38(2), 323-355.

Cummins, J. D., Rubio-Misas, M., Zi, H., 2004. The Effect of Organizational Structure on Efficiency: Evidence from the Spanish Insurance Industry. Journal of Banking and Finance 28(12), 3113-3150.

Cummins, J. D., Tennyson, S., Weiss, M. A., 1999a. Consolidation and Efficiency in the U.S. Life Insurance Industry. Journal of Banking and Finance 23(2-4), 325-357.

Cummins, J. D., Turchetti, G., Weiss, M. A., 1996. Productivity and Technical Efficiency in the Italian Insurance Industry. Working Paper, Wharton Financial Institutions Center, University of Pennsylvania, PA.

Cummins, J. D., Weiss, M. A., 2002. The Global Market for Reinsurance: Consolidation, Capacity, and Efficiency. Working Paper.

Cummins, J. D., Weiss, M. A., 2013. Analyzing Firm Performance in the Insurance Industry Using Frontier Efficiency Methods and Productivity Methods. In: Dionne, G. (Ed.), Handbook of Insurance. Springer Science+Business Media (New York), pp. 795-861.

Cummins, J. D., Weiss, M. A., Xie, X., Zi, H., 2010. Economies of Scope in Financial Services: A DEA Efficiency Analysis of the US Insurance Industry. Journal of Banking and Finance 34(7), 1525-1539.

Cummins, J. D., Weiss, M. A., Zi, H., 1999b. Organizational Form and Efficiency: The Coexistence of Stock and Mutual Property-Liability Insurers. Management Science 45(9), 1254-1269.

Cummins, J. D., Xie, X., 2008. Mergers and Acquisitions in the US Property-Liability Insurance Industry: Property and Efficiency Effects. Journal of Banking and Finance 32(1), 30-55.

Cummins, J. D., Xie, X., 2013. Efficiency, Productivity, and Scale Economies in the U.S. Property-Liability Insurance Industry. Journal of Productivity Analysis 39(2), 141-164. 
Cummins, J. D., Zi, H., 1998. Comparison of Frontier Efficiency Methods: An Application to the US Life Insurance Industry. Journal of Productivity Analysis 10(2), 131-152.

Davutyan, N., Klumpes, P. J. M., 2008. Consolidation and Efficiency in the Major European Insurance Markets: A Non-Discretionary Inputs Approach. Working Paper.

Diacon, S., 2001. The Efficiency of UK General Insurance Companies. Working Paper, Center for Risk \& Insurance Studies, University of Nottingham.

Diacon, S., Starkey, K., O’Brien, C., 2002. Size and Efficiency in European Long-Term Insurance Companies: An International Comparison. Geneva Papers on Risk and Insurance-Issues and Practice 27(3), 444-466.

Diboky, F., Ubl, E., 2007. Ownership and Efficiency in the German Life Insurance Market: A DEA Bootstrap Approach. Working Paper, University of Vienna.

Donni, O., Fecher, F., 1997. Efficiency and Productivity of the Insurance Industry in the OECD Countries. Geneva Papers on Risk and Insurance 22(4), 523-535.

Eling, M., Luhnen, M., 2010a. Frontier Efficiency Methodologies to Measure Performance in the Insurance Industry: Overview, Systematization, and Recent Developments. Geneva Papers on Risk and Insurance 35(2), 217-265.

Eling, M., Luhnen, M., 2010b. Efficiency in the International Insurance Industry: A Cross-Country Comparison. Journal of Banking and Finance 34(7), 1497-1509.

Ennsfellner, K. C., Lewis, D., Anderson, R. I., 2004. Production Efficiency in the Austrian Insurance Industry: A Bayesian Examination. Journal of Risk and Insurance 71(1), 135-159.

Enz, R., 2000. The S-Curve Relation Between per-Capita Income and Insurance Penetration. Geneva Papers on Risk and Insurance-Issues and Practice 25(3), 396-406.

Epermanis, K., Harrington, S. E., 2006. Market Discipline in Property/Casualty Insurance: Evidence from Premium Growth Surrounding Changes in Financial Strength Ratings. Journal of Money, Credit and Banking 38(6), 1515-1544.

Erhemjamts, O., Leverty, J. T., 2010. The Demise of the Mutual Organization Form: An Investigation of the Life Insurance Industry. Journal of Money, Credit and Banking 42(6), 1011-1036.

Fecher, F., Kessler, D., Perelman, S., Pestieau, P., 1993. Productive Performance of the French Insurance Industry. Journal of Productivity Analysis 4(1-2), 77-93.

Fecher, F., Perelman, S., Pestieau, P., 1991. Scale Economies and Performance in the French Insurance Industry. Geneva Papers on Risk and Insurance-Issues and Practice 16(3), 315-326.

Fenn, P., Vencappa, D., Diacon, S., Klumpes, P., O’Brien, C., 2008. Market Structure and the Efficiency of European Insurance Companies: A Stochastic Frontier Analysis. Journal of Banking and Finance 32(1), 86100.

Grace, M. F., Leverty, J. T., Phillips, R. D., Shimpi, P., 2014. The Value of Investing in Enterprise Risk Management. Journal of Risk and Insurance (Early View - Online Version) 9999(9999), 1-28, last accessed: February 8, 2014 (DOI: 10.1111/jori.12022).

Grace, M. F., Timme, S. G., 1992. An Examination of Cost Economies in the United States Life Insurance Industry. Journal of Risk and Insurance 59(1), 72-103.

Greene, W. H., Segal, D., 2004. Profitability and Efficiency in the US Life Insurance Industry. Journal of Productivity Analysis 21(3), 229-247.

Hardwick, P., 1997. Measuring Cost Efficiency in the UK Life Insurance Industry. Applied Financial Economics 7(1), 37-44.

Hitt, M. A., Hoskisson, R. E., Kim, H., 1997. International Diversification: Effects on Innovation and Firm Performance in Product-Diversified Firms. Academy of Management Journal 40(4), 767-777.

Hitt, M. A., Tihanyi, L., Miller, T., Connelly, B., 2006. International Diversification: Antecedents, Outcomes, and Moderators. Journal of Management 32(6), 831-867.

Huang, W., Eling, M., 2013. An Efficiency Comparison of the Non-Life Insurance Industry in the BRIC Countries. European Journal of Operational Research 226(3), 577-591.

Hussels, S., Ward, D. R., 2007. The Impact of Deregulation on the German and UK Life Insurance Markets: An Analysis of Efficiency and Productivity Between 1991 and 2002. Working Paper, SOM Research Paper Series 4/07, Cranfield University.

Hwang, T., Gao, S. S., 2005. An Empirical Study of Cost Efficiency in the Irish Life Insurance Industry. International Journal of Accounting, Auditing and Performance Evaluation 2(3), 264-280.

Kao, C., Hwang, S.-N. 2008. Efficiency Decomposition in Two-Stage Data Envelopment Analysis: An Application to Non-Life Insurance Companies in Taiwan. European Journal of Operational Research 185(1), 418429.

Kao, C., Hwang, S.-N. 2014. Multi-period Efficiency and Malmquist Productivity Index in Two-stage Production Systems. European Journal of Operational Research 232(3), 512-521.

Katrishen, F. A., Scordis, N. A., 1998. Economies of Scale in Services: A Study of Multinational Insurers. Journal of International Business Studies 29(2), 305-323. 
Kotabe, M., Srinivasan, S. S., and Aulakh, P. S., 2002. Multinationality and Firm Performance: The Moderating Role of Marketing and R\&D Activities. Journal of International Business Studies 33(1), 79-97.

Leverty, J. T., Grace, M. F., 2010. The Robustness of Output Measures in Property-Liability Insurance Efficiency Studies. Journal of Banking and Finance 34(7), 1510-1524.

Lu, J. W., Beamish, P. W., 2004. International Diversification and Firm Performance: The S-Curve Hypothesis. Academy of Management Journal 47(4), 598-608.

Luhnen, M., 2009. Determinants of Efficiency and Productivity in German Property-Liability Insurance: Evidence from 1995-2006. Geneva Papers on Risk and Insurance 34(3), 483-505.

Mahlberg, B., Url, T., 2003. Effects of the Single Market on the Austrian Insurance Industry. Empirical Economics 28(4), 813-838.

Meador, J. W., Ryan Jr., H. E., Schellhorn, C. D., 2000. Product Focus Versus Diversification: Estimates of XEfficiency for the U.S. Life Insurance Industry. In: Harker, P. T., Zenios, S. A., (Eds.), Performance of Financial Institutions: Efficiency, Innovation, Regulation. Cambridge University Press, pp. 175-198.

Mester, L. J., 1991. Agency Costs Among Savings and Loans. Journal of Financial Intermediation 1(3), 257278.

Pastor, J. T., 1996. Translation Invariance in Data Envelopment Analysis: A generalization. Annals of Operations Research 66(2), 91-102.

Porter, M. E., 1980. Competitive Strategies: Techniques for Analyzing Industries and Competitors. New York: Free Press.

Qiu, S., Chen, B., 2006. Efficiencies of Life Insurers in China-An Application of Data Envelopment Analysis. Working Paper.

Rai, A., 1996. Cost Efficiency of International Insurance Firms. Journal of Financial Services Research 10(3), 213-233.

Ruigrok, W., Wagner, H., 2003. Internationalization and Performance: An Organizational Learning Perspective. Management International Review 43(1), 63-73.

Simar, L., Wilson, P. W., 1999. Estimating and Bootstrapping Malmquist Indices. European Journal of Operational Research 115(3), 459-471.

Simar, L., Wilson, P. W., 2000 A General Methodology for Bootstrapping in Nonparametric Frontier Models. Journal of Applied Statistics 27(6), 779-802.

Simar, L., Wilson, P. W., 2007. Estimation and Inference in Two-Stage, Semi-Parametric Models of Production Processes. Journal of Econometrics 136(1), 31-64.

Simar, L., Wilson, P. W., 2011. Two-stage DEA: caveat emptor. Journal of Productivity Analysis 36(2), 205218.

Swiss Insurance Association (SIA), 2014. Zahlen und Fakten 2014 der privaten Versicherungswirtschaft (Figures and Facts 2014 for the private Insurance Economy) (Swiss Insurance Association, Zurich, www.svv.ch).

Swiss Re, 2013. World Insurance in 2012: Progressing on the Long and Winding Road to Recovery. Sigma No. 3/2013, Zurich.

Trigo-Gamarra, L., Growitsch, C., 2010. Comparing Single- and Multichannel Distribution Strategies in the German Life Insurance Market: An Analysis of Cost and Profit Efficiency. Schmalenbach Business Review 62(4), 401-417.

Vencappa, D., Fenn, P., Diacon, S., 2013. Productivity Growth in the European Insurance Industry: Evidence from Life and Non-Life Companies. International Journal of the Economics of Business 20(2), 281-305.

Weiss, M. A., 1991. International P/L Insurance Output, Input, and Productivity Comparisons. Geneva Papers on Risk and Insurance Theory 16(2), 179-200.

Wilson, P. W., 1993. Detecting Outliers in Deterministic Nonparametric Frontier Models with Multiple Outputs. Journal of Business and Economics Statistics 11(3), 319-323.

Worthington, A. C., Hurley, E. V., 2002. Cost Efficiency in Australian General Insurers: A Non-Parametric Approach. British Accounting Review 34(1), 89-108.

Yang, H. L., Pollitt, M., 2009. Incorporating Both Undesirable Outputs and Uncontrollable Variables into DEA: The Performance of Chinese Coal-Fired Power Plants. European Journal of Operational Research 197(3), 1095-1105.

Yuengert, A. M., 1993. The Measurement of Life Insurance: Estimates of a Mixed Normal-Gamma Error Model. Journal of Banking and Finance 17(2-3), 483-496.

Zaheer, S., 1995. Overcoming the Liability of Foreignness. Academy of Management Journal 38(2), $341-363$.

Zanghieri, P., 2008. Efficiency of European Insurance Companies: Do Local Factors Matter? Working Paper.

Zhang, Y., Bartels, R., 1998. The Effect of the Sample Size on the Mean Efficiency in DEA with an Application to Electricity Distribution in Australia, Sweden and New Zealand. Journal of Productivity Analysis 9(3), 187-204. 


\section{Supplemental Material for Online Publication Only}

\section{Appendix A: Literature}

Table A.1 Coverage of Switzerland in Cross-Country Efficiency Research

\begin{tabular}{|c|c|c|c|}
\hline Paper & Data Sample & Period & Results for Switzerland \\
\hline Weiss (1991) & $\begin{array}{l}6 \text { OECD countries/ } \\
\text { Property/liability }\end{array}$ & $1975-1987$ & Higher than average productivity growth \\
\hline Rai (1996) & $\begin{array}{l}11 \text { OECD countries/ } \\
\text { life and non-life }\end{array}$ & 1988-1992 & Lower than average cost efficiency \\
\hline Donni and Fecher (1997) & $\begin{array}{l}15 \text { OECD countries/ } \\
\text { life and non-life }\end{array}$ & $1983-1991$ & $\begin{array}{l}\text { High degree of technical efficiency, but lowest } \\
\text { productivity improvements ( }+1 \% \text { p.a.) for all } 15 \\
\text { countries }\end{array}$ \\
\hline Diacon (2001) & $\begin{array}{l}6 \text { European countries/ } \\
\text { general insurance }\end{array}$ & 1999 & Average efficiency \\
\hline Diacon et al. (2002) & $\begin{array}{l}15 \text { European countries/ } \\
\text { life and health }\end{array}$ & 1996-1999 & Average efficiency \\
\hline Davutyan and Klumpes (2008) & $\begin{array}{l}7 \text { European countries/ } \\
\text { life and non-life }\end{array}$ & $1997-2001$ & $\begin{array}{l}\text { Average efficiency for life, but high efficiency } \\
\text { for non-life }\end{array}$ \\
\hline Zanghieri (2008) & $\begin{array}{l}14 \text { European countries/ } \\
\text { life and non-life }\end{array}$ & 1997-2006 & Higher than average efficiency \\
\hline Eling and Luhnen (2010b) & $\begin{array}{l}36 \text { countries worldwide/ } \\
\text { life and non-life }\end{array}$ & $2002-2006$ & Higher than average efficiency \\
\hline
\end{tabular}


Appendix B: Productivity Development per Year

Table B.1 Malmquist Index of Total Factor Productivity (Single Periods)

\begin{tabular}{|c|c|c|c|c|c|c|}
\hline Period & $\begin{array}{l}\text { No. of } \\
\text { firms }\end{array}$ & $\begin{array}{l}\text { Technical } \\
\text { change }\end{array}$ & $\begin{array}{l}\text { Technical } \\
\text { efficiency } \\
\text { change } \\
\end{array}$ & $\begin{array}{l}\text { Pure technical } \\
\text { efficiency } \\
\text { change }\end{array}$ & $\begin{array}{l}\text { Scale } \\
\text { efficiency } \\
\text { change } \\
\end{array}$ & $\begin{array}{l}\text { Total factor } \\
\text { productivity } \\
\text { change }\end{array}$ \\
\hline \multicolumn{7}{|c|}{ Panel A: life insurance } \\
\hline $1997-1998$ & 30 & $0.98 *$ & 1.00 & $1.00 *$ & 1.00 & $0.98^{*}$ \\
\hline 1998-1999 & 29 & 1.00 & 1.00 & 1.00 & 1.00 & 1.00 \\
\hline 1999-2000 & 28 & 0.99 & 1.00 & $1.00 *$ & 1.00 & 0.99 \\
\hline $2000-2001$ & 24 & 1.01 & 1.00 & 1.00 & 1.00 & 1.01 \\
\hline 2001-2002 & 19 & 1.04 & 1.00 & 1.00 & 1.00 & 1.04 \\
\hline $2002-2003$ & 20 & $0.96^{*}$ & 1.00 & $1.00 *$ & 1.00 & $0.96^{*}$ \\
\hline 2003-2004 & 23 & 0.99 & 1.00 & 1.00 & 1.01 & 0.99 \\
\hline 2004-2005 & 22 & $0.97 * *$ & 1.00 & 1.00 & 1.00 & $0.96^{* *}$ \\
\hline $2005-2006$ & 21 & 0.99 & 0.99 & 1.00 & 1.00 & 0.99 \\
\hline 2006-2007 & 21 & 1.01 & 1.00 & 1.00 & 1.00 & 1.01 \\
\hline $2007-2008$ & 20 & 0.99 & $0.99 * *$ & $0.99 * *$ & 1.00 & 0.98 \\
\hline $2008-2009$ & 20 & $0.95 *$ & 1.01 & $1.02 *$ & 0.99 & 0.96 \\
\hline 2009-2010 & 21 & 1.00 & $1.00 * * *$ & 1.00 & 1.00 & 1.00 \\
\hline 2010-2011 & 20 & 1.01 & 1.00 & 1.00 & 1.00 & 1.01 \\
\hline 2011-2012 & 18 & 1.00 & $1.01 * *$ & 1.01 & 1.00 & 1.01 \\
\hline $2012-2013$ & 19 & 1.01 & $1.00 * *$ & 1.00 & 1.00 & 1.01 \\
\hline \multicolumn{7}{|c|}{ Panel B: $p / c$ insurance } \\
\hline $1997-1998$ & 60 & 1.03 & 1.00 & 1.00 & 1.01 & 1.02 \\
\hline 1998-1999 & 61 & 1.00 & 1.00 & 0.99 & $1.01 * *$ & 1.00 \\
\hline 1999-2000 & 60 & 0.99 & 1.03 & 1.04 & 0.99 & 1.02 \\
\hline $2000-2001$ & 58 & 1.01 & 1.01 & 1.02 & 0.99 & 1.01 \\
\hline 2001-2002 & 56 & $1.02 * *$ & 0.99 & $0.97 * * *$ & 1.01 & 1.01 \\
\hline $2002-2003$ & 62 & 1.01 & 1.00 & 0.99 & $1.01 *$ & 1.01 \\
\hline 2003-2004 & 60 & 0.99 & $1.02 * *$ & $1.02 * *$ & 1.00 & 1.01 \\
\hline 2004-2005 & 60 & 1.01 & 1.01 & $1.02 * *$ & 0.99 & 1.02 \\
\hline 2005-2006 & 63 & 1.00 & $1.01 * * *$ & 1.02 & 1.03 & $1.02 *$ \\
\hline $2006-2007$ & 53 & 1.03 & $1.02 * *$ & $1.02 * *$ & 1.00 & 1.05 \\
\hline 2007-2008 & 54 & $1.05^{*}$ & $0.94 * * *$ & $0.96 * *$ & $0.99 * *$ & 0.99 \\
\hline 2008-2009 & 60 & 1.01 & 1.10 & $1.10 *$ & 0.99 & 1.11 \\
\hline 2009-2010 & 58 & 1.02 & $0.98 * * *$ & $0.97 * * *$ & 1.01 & 0.99 \\
\hline 2010-2011 & 55 & $1.07 * * *$ & $0.96 * * *$ & 1.00 & $0.96 * * *$ & $1.03 *$ \\
\hline 2011-2012 & 58 & $0.97 * * *$ & $1.03 * *$ & 1.01 & $1.02 * *$ & 1.00 \\
\hline $2012-2013$ & 56 & $0.96 * * *$ & $1.04 * * *$ & $1.02 * * *$ & $1.01 * *$ & 0.99 \\
\hline \multicolumn{7}{|c|}{ Panel C: reinsurance } \\
\hline $1997-1998$ & 22 & $0.95 * * *$ & 1.11 & 1.00 & 1.13 & 1.06 \\
\hline 1998-1999 & 23 & $1.03 * *$ & 0.99 & 1.03 & 0.97 & 1.02 \\
\hline 1999-2000 & 25 & 1.00 & 1.01 & 1.00 & 1.01 & 1.01 \\
\hline 2000-2001 & 29 & $1.05 * *$ & 0.98 & 0.96 & 1.06 & 1.03 \\
\hline 2001-2002 & 31 & 1.06 & $0.95 * *$ & 1.03 & $0.94 * *$ & 1.00 \\
\hline $2002-2003$ & 36 & 1.00 & 1.02 & 1.00 & 1.02 & 1.02 \\
\hline 2003-2004 & 37 & 1.00 & 1.04 & 1.02 & 1.02 & 1.05 \\
\hline 2004-2005 & 39 & 1.03 & 1.02 & 1.01 & 1.01 & 1.05 \\
\hline 2005-2006 & 48 & 1.05 & 1.05 & 1.04 & 1.01 & 1.10 \\
\hline 2006-2007 & 47 & $0.96 * * *$ & 1.02 & 1.03 & 1.00 & 0.98 \\
\hline 2007-2008 & 47 & 1.13 & $0.95 * *$ & 0.99 & 0.96 & 1.07 \\
\hline 2008-2009 & 52 & 1.04 & 1.06 & 1.01 & 1.06 & 1.13 \\
\hline 2009-2010 & 53 & 1.00 & 1.03 & 0.97 & $1.08 * *$ & 1.03 \\
\hline 2010-2011 & 54 & $0.97 * * *$ & 1.00 & 1.02 & 0.99 & 0.97 \\
\hline 2011-2012 & 52 & $1.04 * * *$ & 1.00 & 1.03 & $0.97 * *$ & 1.04 \\
\hline 2012-2013 & 53 & 1.00 & 1.01 & 0.99 & 1.02 & 1.01 \\
\hline
\end{tabular}


Appendix C: Descriptive Statistics of Covariates

Table C.1 Descriptive Statistics for the Covariates used in the Regression

\begin{tabular}{|c|c|c|c|c|c|c|c|}
\hline & $\begin{array}{r}\text { Int'l } \\
\text { div. }\end{array}$ & Size & Specialization & $\begin{array}{r}\begin{array}{r}\text { Organizational } \\
\text { form }\end{array} \\
\end{array}$ & Leverage & $\begin{array}{r}\begin{array}{r}\text { Premium } \\
\text { growth }\end{array} \\
\end{array}$ & $\begin{array}{r}\text { Company } \\
\text { age } \\
\end{array}$ \\
\hline \multicolumn{8}{|c|}{ Panel A: life insurance } \\
\hline Mean & 0.044 & $13 ’ 136$ & 0.606 & 0.919 & 0.942 & 0.006 & 67.8 \\
\hline Std. Dev. & 0.143 & $24^{\prime} 934$ & 0.202 & 0.273 & 0.095 & 0.263 & 45.3 \\
\hline Min. & 0.000 & 11 & 0.300 & 0.000 & 0.323 & -0.944 & 2.0 \\
\hline Max. & 0.985 & $132{ }^{\prime} 489$ & 1.000 & 1.000 & 0.997 & 1.444 & 157.0 \\
\hline \multicolumn{8}{|c|}{ Panel $B: p / c$ insurance } \\
\hline Mean & 0.072 & 1’959 & 0.725 & 0.799 & 0.668 & 0.027 & 65.6 \\
\hline Std. Dev. & 0.202 & $8^{\prime} 787$ & 0.315 & 0.401 & 0.250 & 0.272 & 49.1 \\
\hline Min. & 0.000 & 0.5 & 0.188 & 0.000 & 0.025 & -0.830 & 2.0 \\
\hline Max. & 1.000 & $87^{\prime} 059$ & 1.000 & 1.000 & 0.993 & 2.674 & 188.0 \\
\hline \multicolumn{8}{|c|}{ Panel C: reinsurance } \\
\hline Mean & -- & 2’276 & 0.662 & -- & 0.622 & 0.094 & 21.4 \\
\hline Std. Dev. & -- & $11^{\prime} 131$ & 0.292 & -- & 0.245 & 0.724 & 26.1 \\
\hline Min. & -- & 1 & 0.176 & -- & 0.000 & -1.010 & 2.0 \\
\hline Max. & -- & 103’389 & 1.000 & -- & 0.990 & 5.612 & 151.0 \\
\hline
\end{tabular}

Note: Covariates "Int'l div." show the ratio of premiums earned abroad to total premiums earned, for "Size" we show total assets (in million CHF), "Specialization" is the Herfindahl Index of premiums per each line of business, "Organizational form" ( 1 = stock, $0=$ mutual $)$ show scores for the dummy variable, "Leverage" is the ratio of debt capital to total assets, "Premium growth" the proportional change in premiums, and for "Company age" we provide the company age in years. 
Table C.2 Correlations among the Covariates used in the Regressions

\begin{tabular}{|c|c|c|c|c|c|c|c|c|}
\hline & Year & $\begin{array}{l}\text { Int'l } \\
\text { div. }\end{array}$ & Size & Specialization & $\begin{array}{l}\text { Organizational } \\
\text { form }\end{array}$ & Leverage & $\begin{array}{l}\text { Premium } \\
\text { growth }\end{array}$ & $\begin{array}{l}\text { Company } \\
\text { age }\end{array}$ \\
\hline \multicolumn{9}{|c|}{ Panel A: life insurance } \\
\hline Year & 1.00 & & & & & & & \\
\hline $\begin{array}{l}\text { Int'l } \\
\text { diversification }\end{array}$ & $-0.09 *$ & 1.00 & & & & & & \\
\hline Size & 0.08 & $0.38 * * *$ & 1.00 & & & & & \\
\hline Specialization & $0.13 * *$ & -0.05 & -0.04 & 1.00 & & & & \\
\hline $\begin{array}{l}\text { Organizational } \\
\text { form }\end{array}$ & -0.02 & $0.09 *$ & $0.15 * * *$ & $-0.45 * * *$ & 1.00 & & & \\
\hline Leverage & -0.03 & 0.07 & $0.16^{* * *}$ & $-0.18 * * *$ & $-0.10 * *$ & 1.00 & & \\
\hline $\begin{array}{l}\text { Premium } \\
\text { growth }\end{array}$ & $-0.13 * *$ & 0.07 & -0.01 & -0.04 & 0.04 & -0.07 & 1.00 & \\
\hline Company age & 0.03 & $0.14 * * *$ & $0.59 * * *$ & $-0.10^{*}$ & $-0.13 * * *$ & $0.32 * * *$ & 0.00 & 1.00 \\
\hline \multicolumn{9}{|c|}{ Panel B: $p / c$ insurance } \\
\hline Year & 1.00 & & & & & & & \\
\hline $\begin{array}{l}\text { Int'l } \\
\text { diversification }\end{array}$ & $-0.15^{* * *}$ & 1.00 & & & & & & \\
\hline Size & 0.04 & $0.27 * * *$ & 1.00 & & & & & \\
\hline Specialization & $0.13 * * *$ & $-0.16 * * *$ & $-0.32 * * *$ & 1.00 & & & & \\
\hline $\begin{array}{l}\text { Organizational } \\
\text { form }\end{array}$ & -0.02 & $0.12 * * *$ & $0.08 * * *$ & $-0.09 * * *$ & 1.00 & & & \\
\hline Leverage & $-0.10 * * *$ & $-0.10 * * *$ & $0.13 * * *$ & $-0.30 * * *$ & $0.17 * * *$ & 1.00 & & \\
\hline $\begin{array}{l}\text { Premium } \\
\text { growth }\end{array}$ & -0.04 & 0.03 & -0.03 & $0.06^{*}$ & 0.02 & -0.04 & 1.00 & \\
\hline Company age & -0.05 & $0.09 * * *$ & $0.29 * * *$ & $-0.48 * * *$ & $-0.49 * * *$ & $0.23 * * *$ & $-0.06^{*}$ & 1.00 \\
\hline \multicolumn{9}{|c|}{ Panel C: reinsurance } \\
\hline Year & 1.00 & & & & & & & \\
\hline $\begin{array}{l}\text { Int'l } \\
\text { diversification }\end{array}$ & -- & -- & & & & & & \\
\hline Size & 0.01 & -- & 1.00 & & & & & \\
\hline Specialization & $0.10^{* * *}$ & -- & $-0.27 * * *$ & 1.00 & & & & \\
\hline $\begin{array}{l}\text { Organizational } \\
\text { form }\end{array}$ & -- & -- & -- & -- & -- & & & \\
\hline Leverage & $-0.24 * * *$ & -- & $0.16^{* * *}$ & $-0.36 * * *$ & -- & 1.00 & & \\
\hline $\begin{array}{l}\text { Premium } \\
\text { growth }\end{array}$ & $-0.07 *$ & -- & 0.01 & 0.00 & -- & 0.00 & 1.00 & \\
\hline Company age & $0.15^{* * *}$ & -- & $0.77 * * *$ & $-0.37 * * *$ & -- & $0.29 * * *$ & 0.02 & 1.00 \\
\hline
\end{tabular}

Note: $* * *, * *$, and $*$ denote statistical significance at the $1 \%, 5 \%$, and $10 \%$ levels, respectively. 


\section{Appendix D: Potential Cost Savings and Revenue Enhancements}

To assess the monetary implications of changes in cost and revenue efficiency, we compute the cost savings (or losses) and revenue enhancements (or gains) in 2010 CHF a firm can achieve by actively changing the proportion of international diversification, firm size, strategic decisions about specialization or organizational form, equity and debt capital (leverage) substitutions and changes in premium growth. Note that we do not discuss the results for company age, since age is not a property that a firm can actively control. We follow the approach used in Grace et al. (2014), and by that use OLS, which provides consistent results with the truncated regression in Section 4.3 (Table 5). Furthermore, we only focus on the regression results for CE and RE that were significant in the OLS regression. The estimated average cost savings and revenue enhancements for the mentioned covariates are listed in Table D.1.

Table D.1 Cost Savings and Revenue Enhancements for Changes in Covariates

\begin{tabular}{|c|c|c|c|c|c|c|}
\hline \multirow[b]{2}{*}{ Average total costs } & \multicolumn{2}{|c|}{ life insurance } & \multicolumn{2}{|c|}{ p/c insurance } & \multicolumn{2}{|c|}{ reinsurance } \\
\hline & $14,213.35$ & & $2,420.53$ & & $2,871.48$ & \\
\hline Average total revenues & & $19,328.80$ & & $3,446.11$ & & $6,101.99$ \\
\hline & $\begin{array}{l}\text { Cost } \\
\text { savings }\end{array}$ & $\begin{array}{l}\text { Revenue } \\
\text { enhancement }\end{array}$ & $\begin{array}{l}\text { Cost } \\
\text { savings }\end{array}$ & $\begin{array}{l}\text { Revenue } \\
\text { enhancement }\end{array}$ & $\begin{array}{l}\text { Cost } \\
\text { savings }\end{array}$ & $\begin{array}{l}\text { Revenue } \\
\text { enhancement }\end{array}$ \\
\hline Int'l diversification & 997.87 & $2,048.76$ & -339.94 & 337.59 & -- & - \\
\hline Size & 259.75 & 378.57 & 90.18 & 27.94 & & -135.05 \\
\hline Specialization & & $-1,630.68$ & 269.32 & 229.86 & -560.78 & -279.47 \\
\hline Organizational form & $-1,472.24$ & $-3,101.09$ & -113.58 & & -- & -- \\
\hline Leverage & $-3,347.18$ & $-6,653.78$ & -295.17 & -608.06 & -901.77 & -223.71 \\
\hline Premium growth & & 977.38 & -153.68 & & & 80.16 \\
\hline Company age & -- & -- & -- & -- & -- & -- \\
\hline
\end{tabular}

For a Swiss life insurance firm, increasing its international activity by one unit (i.e., increase of premiums written abroad to total premiums ratio by $1 \%$ ), potential cost savings of about CHF 998 million on average are feasible, while cost savings for $\mathrm{p} / \mathrm{c}$ insurers turn into losses of about CHF 340 million on average. The significant difference is explained by the different regression coefficients (providing the sign; Table 5) and by the fact that the average total costs for life insurers are generally much higher. Although increasing international activity leads to additional costs, revenues can be increased for $\mathrm{p} / \mathrm{c}$ insurance by about a similar amount (about CHF 338 million on average). Also, for the life insurance industry, revenues can be enhanced by about CHF 2,049 million. Monetary advantages generated by increasing firm size are twofold in life and $\mathrm{p} / \mathrm{c}$ insurance. On the one hand, significant cost savings for both sectors can be realized. In the life insurance market, a one unit increase in size (i.e., one unit increase in the natural logarithm of total assets) would result in CHF 260 million of cost savings, while for $\mathrm{p} / \mathrm{c}$ this amount is about CHF 90 million. On the other hand, increasing firm size can lead to revenue enhancements (life: CHF 379 million; p/c: CHF 28 million). This latter result is consistent only for life and $\mathrm{p} / \mathrm{c}$. An increase in size leads to revenue losses 
of about CHF 135 million in the reinsurance sector. Increasing leverage by one unit (i.e., a 1\% increase in debt to total assets ratio) would cause essential cost and revenue losses in all sectors (life: in total about CHF 10,000 million; p/c: in total about CHF 903 million; reinsurance: in total about CHF 1,125 million). In addition, further losses can occur by choosing stock as an organizational form. However, this suggestion may not be feasible in the "real" world, where there are sometimes other factors that motivate this choice, not just cost saving and revenue improving potential. Other revenue gains and losses might occur due to higher premium growth rates or from being too specialized.

As seen in Section 4.4.3, looking exclusively at linear relations is not sufficient; interactions between different means can cause gains, even though these results are not presented that way in Table D.1 (e.g., in p/c insurance where we discovered that international diversification is not detrimental for all types of firms). 


\section{Appendix E: Economies of Scale}

In Table 3 we find that for all three subsectors, SE is close to one, indicating that not very much inefficiency is due to scale inefficiencies. Since the scale efficiency measure does not provide any information about how the scale inefficiency occurred (i.e., by increasing or decreasing return to scale), we investigate this in more detail by computing returns to scale for every firm in our sample. ${ }^{30}$ Results showing the development over time are listed in Table E.1.

The results show that most of the life insurance firms are operating under CRS. The majority of $\mathrm{p} / \mathrm{c}$ and reinsurers mainly operate under IRS. For reinsurance, however, this number is very similar to the number of firms under IRS and DRS. Furthermore, the life insurance market shows the highest average relative number of firms operating under optimal scale in the sample (about 41\%). Just up to about 23\% (in p/c) and 35\% (in reinsurance) obtain optimal scale on average in the other sectors. Nevertheless, these numbers of firms under CRS are much higher than the results obtained by Cummins and Zi (1998) for the U.S. life market and by Cummins and Xie (2013) for the U.S. p/l insurance industry.

Looking at development over time reveals no clear patterns. In the life insurance sector, the relative number of firms operating under IRS seems to decrease until 2003, increase from 2003-2005, and then after 2005 fluctuates on a three-year basis. A similar pattern can be observed for DRS, which, however, decreases slightly after 2005. These two developments are contrary to the development of CRS, which seem to increase in the years after 2005 . In $\mathrm{p} / \mathrm{c}$ insurance, the proportion of firms operating with CRS does not show any significant trend. Higher variations can be seen in the IRS and DRS categories, but those balance each other, such that the CRS amount stays more or less constant. Cummins and Xie (2013), analyzing the U.S. p/l market, also were not able to prove statistically significant trends over time. In reinsurance, no clear pattern can be observed. The proportions of all three scale categories vary over time, but no massive increases or decreases can be seen.

Following Cummins and Zi (1998) and Cummins and Xie (2013), we also analyze size deciles in order to identify size thresholds at which the economies of scale properties seem to change. The results are given in Table E.2.

30 For this analysis we use data without shift of the first output in the estimation of the efficiency scores and exclude all observations with non-positive inputs and outputs. Although our model is translation invariant and, theoretically, shifts are applicable, the results for the returns to scale showed some massive effects, since by the shifts the relation between CRS and VRS frontiers changed. The sample used in this part of the Online-Appendix consists of 389 firm-year observations (34 companies) in life, 993 firm-year observations (86 companies) in $\mathrm{p} / \mathrm{c}$, and 704 firm-year observations (101 companies) in reinsurance. 
Table E.1 Returns to Scale-Development

\begin{tabular}{|c|c|c|c|c|c|c|}
\hline \multirow[t]{2}{*}{ Years } & \multicolumn{3}{|l|}{ Number of firms } & \multicolumn{3}{|c|}{ ercentage of total firms } \\
\hline & $\begin{array}{l}\text { Increasing return } \\
\text { to scale (IRS) }\end{array}$ & $\begin{array}{l}\text { Constant return } \\
\text { to scale (CRS) }\end{array}$ & $\begin{array}{l}\text { Decreasing return } \\
\text { to scale (DRS) }\end{array}$ & IRS $\%$ & $\mathrm{CRS} \%$ & DRS $\%$ \\
\hline \multicolumn{7}{|c|}{ Panel A: life insurance } \\
\hline 1997 & 7 & 9 & 15 & 22.6 & 29.0 & 48.4 \\
\hline 1998 & 6 & 10 & 14 & 20.0 & 33.3 & 46.7 \\
\hline 1999 & 5 & 10 & 15 & 16.7 & 33.3 & 50.0 \\
\hline 2000 & 5 & 9 & 14 & 17.9 & 32.1 & 50.0 \\
\hline 2001 & 4 & 13 & 7 & 16.7 & 54.2 & 29.2 \\
\hline 2002 & 3 & 11 & 6 & 15.0 & 55.0 & 30.0 \\
\hline 2003 & 2 & 9 & 12 & 8.7 & 39.1 & 52.2 \\
\hline 2004 & 5 & 9 & 9 & 21.7 & 39.1 & 39.1 \\
\hline 2005 & 8 & 4 & 10 & 36.4 & 18.2 & 45.5 \\
\hline 2006 & 6 & 7 & 9 & 27.3 & 31.8 & 40.9 \\
\hline 2007 & 7 & 8 & 6 & 33.3 & 38.1 & 28.6 \\
\hline 2008 & 3 & 8 & 7 & 16.7 & 44.4 & 38.9 \\
\hline 2009 & 5 & 9 & 7 & 23.8 & 42.9 & 33.3 \\
\hline 2010 & 8 & 9 & 2 & 42.1 & 47.4 & 10.5 \\
\hline 2011 & 6 & 9 & 4 & 31.6 & 47.4 & 21.1 \\
\hline 2012 & 3 & 11 & 5 & 15.8 & 57.9 & 26.3 \\
\hline 2013 & 6 & 11 & 2 & 31.6 & 57.9 & 10.5 \\
\hline Mean & 5.2 & 9.2 & 8.5 & 23.4 & 41.2 & 35.4 \\
\hline \multicolumn{7}{|c|}{ Panel B: $p / c$ insurance } \\
\hline 1997 & 19 & 16 & 26 & 31.1 & 26.2 & 42.6 \\
\hline 1998 & 16 & 15 & 31 & 25.8 & 24.2 & 50.0 \\
\hline 1999 & 25 & 14 & 22 & 41.0 & 23.0 & 36.1 \\
\hline 2000 & 31 & 12 & 18 & 50.8 & 19.7 & 29.5 \\
\hline 2001 & 27 & 15 & 17 & 45.8 & 25.4 & 28.8 \\
\hline 2002 & 27 & 13 & 19 & 45.8 & 22.0 & 32.2 \\
\hline 2003 & 27 & 14 & 21 & 43.5 & 22.6 & 33.9 \\
\hline 2004 & 29 & 14 & 18 & 47.5 & 23.0 & 29.5 \\
\hline 2005 & 22 & 13 & 26 & 36.1 & 21.3 & 42.6 \\
\hline 2006 & 24 & 11 & 25 & 40.0 & 18.3 & 41.7 \\
\hline 2007 & 19 & 11 & 23 & 35.8 & 20.8 & 43.4 \\
\hline 2008 & 30 & 10 & 17 & 52.6 & 17.5 & 29.8 \\
\hline 2009 & 21 & 20 & 18 & 35.6 & 33.9 & 30.5 \\
\hline 2010 & 24 & 15 & 15 & 44.4 & 27.8 & 27.8 \\
\hline 2011 & 23 & 12 & 19 & 42.6 & 22.2 & 35.2 \\
\hline 2012 & 20 & 14 & 22 & 35.7 & 25.0 & 39.3 \\
\hline 2013 & 26 & 12 & 15 & 49.1 & 22.6 & 28.3 \\
\hline Mean & 24.1 & 13.6 & 20.7 & 41.4 & 23.3 & 35.4 \\
\hline \multicolumn{7}{|c|}{ Panel C: reinsurance } \\
\hline 1997 & 5 & 10 & 9 & 20.8 & 41.7 & 37.5 \\
\hline 1998 & 7 & 13 & 4 & 29.2 & 54.2 & 16.7 \\
\hline 1999 & 7 & 10 & 7 & 29.2 & 41.7 & 29.2 \\
\hline 2000 & 12 & 9 & 12 & 36.4 & 27.3 & 36.4 \\
\hline 2001 & 15 & 12 & 7 & 44.1 & 35.3 & 20.6 \\
\hline 2002 & 14 & 17 & 10 & 34.1 & 41.5 & 24.4 \\
\hline 2003 & 10 & 14 & 10 & 29.4 & 41.2 & 29.4 \\
\hline 2004 & 6 & 16 & 21 & 14.0 & 37.2 & 48.8 \\
\hline 2005 & 23 & 15 & 13 & 45.1 & 29.4 & 25.5 \\
\hline 2006 & 21 & 16 & 13 & 42.0 & 32.0 & 26.0 \\
\hline 2007 & 22 & 15 & 10 & 46.8 & 31.9 & 21.3 \\
\hline 2008 & 20 & 12 & 17 & 40.8 & 24.5 & 34.7 \\
\hline 2009 & 19 & 17 & 17 & 35.8 & 32.1 & 32.1 \\
\hline 2010 & 22 & 10 & 16 & 45.8 & 20.8 & 33.3 \\
\hline 2011 & 21 & 15 & 14 & 42.0 & 30.0 & 28.0 \\
\hline 2012 & 21 & 18 & 12 & 41.2 & 35.3 & 23.5 \\
\hline 2013 & 17 & 16 & 15 & 35.4 & 33.3 & 31.3 \\
\hline Mean & 15.4 & 13.8 & 12.2 & 36.0 & 34.7 & 29.3 \\
\hline
\end{tabular}


Table E.2 Returns to Scale for Fixed-Size Groups

\begin{tabular}{|c|c|c|c|}
\hline $\begin{array}{l}\text { Asset } \\
\text { Size Class } \\
\end{array}$ & $\begin{array}{l}\text { Increasing returns to scale } \\
\text { (IRS) }\end{array}$ & $\begin{array}{c}\text { Constant returns to scale } \\
\text { (CRS) }\end{array}$ & $\begin{array}{l}\text { Decreasing returns to scale } \\
\text { (DRS) }\end{array}$ \\
\hline \multicolumn{4}{|c|}{ Panel A: life insurance } \\
\hline$\leq 243 \mathrm{M}$ & 11 & 28 & 0 \\
\hline $243 \mathrm{M}-398 \mathrm{M}$ & 21 & 13 & 5 \\
\hline $398 \mathrm{M}-713 \mathrm{M}$ & 29 & 7 & 3 \\
\hline $713 \mathrm{M}-1.4 \mathrm{~B}$ & 11 & 26 & 6 \\
\hline $1.4 \mathrm{~B}-3.6 \mathrm{~B}$ & 12 & 13 & 11 \\
\hline $3.6 \mathrm{~B}-6.0 \mathrm{~B}$ & 4 & 19 & 15 \\
\hline $6.0 \mathrm{~B}-7.1 \mathrm{~B}$ & 0 & 17 & 22 \\
\hline 7.1B-19.6B & 1 & 9 & 28 \\
\hline $19.6 \mathrm{~B}-36.4 \mathrm{~B}$ & 1 & 12 & 26 \\
\hline$>36.4 \mathrm{~B}$ & 0 & 14 & 25 \\
\hline \multicolumn{4}{|c|}{ Panel B: $p / c$ insurance } \\
\hline$\leq 6 \mathrm{M}$ & 70 & 28 & 0 \\
\hline $6 \mathrm{M}-16 \mathrm{M}$ & 58 & 39 & 3 \\
\hline $16 \mathrm{M}-36 \mathrm{M}$ & 71 & 25 & 5 \\
\hline $36 \mathrm{M}-60 \mathrm{M}$ & 72 & 13 & 13 \\
\hline $60 \mathrm{M}-104 \mathrm{M}$ & 53 & 21 & 25 \\
\hline $104 \mathrm{M}-191 \mathrm{M}$ & 50 & 13 & 37 \\
\hline $191 \mathrm{M}-367 \mathrm{M}$ & 22 & 24 & 53 \\
\hline $367 \mathrm{M}-1.4 \mathrm{~B}$ & 10 & 36 & 51 \\
\hline $1.4 \mathrm{~B}-3.2 \mathrm{~B}$ & 2 & 32 & 67 \\
\hline$>3.2 \mathrm{~B}$ & 2 & 0 & 98 \\
\hline \multicolumn{4}{|c|}{ Panel C: reinsurance } \\
\hline$\leq 7 \mathrm{M}$ & 47 & 26 & 1 \\
\hline $7 \mathrm{M}-14 \mathrm{M}$ & 37 & 25 & 3 \\
\hline $14 \mathrm{M}-23 \mathrm{M}$ & 50 & 19 & 1 \\
\hline $23 \mathrm{M}-42 \mathrm{M}$ & 43 & 21 & 7 \\
\hline $42 \mathrm{M}-59 \mathrm{M}$ & 37 & 29 & 6 \\
\hline $59 \mathrm{M}-91 \mathrm{M}$ & 27 & 31 & 19 \\
\hline $91 \mathrm{M}-272 \mathrm{M}$ & 18 & 29 & 24 \\
\hline $272 \mathrm{M}-733 \mathrm{M}$ & 6 & 29 & 38 \\
\hline $733 \mathrm{M}-2.3 \mathrm{~B}$ & 2 & 16 & 52 \\
\hline$>2.3 \mathrm{~B}$ & 0 & 10 & 61 \\
\hline
\end{tabular}

Note: $\mathrm{M}=$ millions of $\mathrm{CHF}, \mathrm{B}=$ billions of $\mathrm{CHF}$.

In life insurance, most firms with total assets below CHF 3.6 billion are operating in the range of IRS and CRS. Life insurers with total assets above CHF 3.6 billion nearly all work under DRS or CRS, and the majority, those with total assets above CHF 6.0B, are operating under DRS. Thus, M\&A activities between firms with less than CHF 3.6 billion in total assets have the potential to reduce production costs, whereas mergers between firms that are above this threshold cannot be justified by cost reduction reasons alone. Even adjusted for exchange rates and the time between the two analyses, the threshold computed for Switzerland is much higher than the threshold observed in Cummins and Zi (1998), but it is lower than the US\$ 15 billion found by Yuengert (1993). This might be because the life insurers in the Swiss sample for 1997-2013 are on average much bigger than the firms in the U.S. sample of Cummins and $\mathrm{Zi}$ (1998) for the period 1988-1992.

Similar statements can be made for $\mathrm{p} / \mathrm{c}$ and reinsurance. $\mathrm{P} / \mathrm{c}$ firms with total assets above $\mathrm{CHF}$ 191 million are already too large, efficiency-wise, such that the majority of these firms oper- 
ate under DRS. Thus, mergers between firms with total assets below CHF 191 million should enable those firms to save production costs. This threshold is close to the one observed in Cummins and Xie (2013) for the U.S. p/l insurance industry over the period 1993-2009. For the reinsurance sample, firm size between CHF 91 million and CHF 272 million in assets is the threshold for the change in the economy of scale property. While firms with total assets above CHF 272 million operate under DRS and CRS, smaller firms with up to CHF 91 million total assets mostly operate under IRS and CRS. Here, a threshold of about CHF 100 million might be reasonable for M\&A recommendations, since a relatively large number of firms in size group CHF 91-272 million operate under IRS.

Note that even among the smallest and largest firms, many operate under CRS. Thus, it is possible for even the largest and smallest firms to attain CRS, indicating that there may be important managerial lessons to be learned from case-study analyses of scale-efficient insurers (see Cummins and Xie, 2013).

The general results are in line with findings from other countries (see, e.g., Yuengert, 1993 and Cummins and Zi, 1998 for the United States; Hardwick, 1997 for the U.K. life market; Luhnen, 2009 for p/l insurance in Germany) and confirm Hypothesis H3(b). 